\title{
Overview of Recent Advances in Immobilisation Techniques for Phenol Oxidases in Solution
}

\author{
Thandanani Ndlovu ${ }^{1}$, Sidy $\mathrm{Ba}^{2}$ and Soraya $\mathrm{P}$ Malinga ${ }^{1, *}$ \\ 1 Department of Chemical Sciences, University of Johannesburg, Doornfontein 2028, South Africa; \\ thandananindlovu15@gmail.com \\ 2 Department of Rural Engineering and Water \& Forest, Institut Polytechnique Rural de Formation et de \\ Recherche Appliquée de Katibougou, Koulikoro BP 06, Mali; Sidy.Ba@USherbrooke.ca \\ * Correspondence: smalinga@uj.ac.za; Tel.: +27-11-559-9008
}

Received: 20 March 2020; Accepted: 10 April 2020; Published: 25 April 2020

check for updates

\begin{abstract}
Over the past two decades, phenol oxidases, particularly laccases and tyrosinases, have been extensively used for the removal of numerous pollutants in wastewaters due to their broad substrate specificity and their ability to use readily accessible molecular oxygen as the essential cofactor. As for other enzymes, immobilisation of laccases and tyrosinases has been shown to improve the performance and efficiency of the biocatalysts in solution. Several reviews have addressed the enzyme immobilisation techniques and the application of phenol oxidases to decontaminate wastewaters. This paper offers an overview of the recent publications, mainly from 2012 onwards, on the various immobilisation techniques applied to laccases and tyrosinases to induce and/or increase the performance of the biocatalysts. In this paper, the emphasis is on the efficiencies achieved, in terms of structural modifications, stability and resistance to extreme conditions $(\mathrm{pH}$, temperature, inhibitors, etc.), reactivity, reusability, and broad substrate specificity, particularly for application in bioremediation processes. The advantages and disadvantages of several enzyme immobilisation techniques are also discussed. The relevance and effectiveness of the immobilisation techniques with respect to wastewater decontamination are critically assessed. A perspective on the future directions for large-scale application of the phenol oxidases in immobilised forms is provided.
\end{abstract}

Keywords: immobilisation techniques; inhibitors; laccases; stability; tyrosinases; wastewater decontamination

\section{Introduction}

In recent years, much research has been conducted to exploit the biochemical and ecological capacity of enzyme-producing fungi to degrade harmful chemicals [1]. The oxidative enzymes produced by fungi are of particular interest because of their potential use in detoxifying environmental contaminants and in the bioremediation of phenolic compounds. Among these enzymes, laccase (EC 1.10.3.2,) and tyrosinase (EC 1.14.18.1), two copper-containing oxidoreductases that catalyse the oxidation of phenolic compounds, thus forming part of the phenol oxidases, stand out as particularly attractive [2,3]. Unlike many other enzymes, both of these phenoloxidases solely require the readily available bimolecular oxygen $\left(\mathrm{O}_{2}\right)$ for their catalytic activity without necessitating additional, often not environmentally friendly, cofactors (e.g., $\mathrm{H}_{2} \mathrm{O}_{2}$ for peroxidases) [4]. In addition to fungi, these enzymes are abundant in various species of living beings (plants, animals, insects, bacteria, etc.) making them potentially endlessly renewable biocatalysts. Notwithstanding their attractiveness, the use of tyrosinase and laccase in solution is hindered by disadvantages associated with any other free enzymes; inter alia, lack of operational and storage stability due to denaturation and loss of activity, cumbersome recovery and product contamination [5]. Those shortcomings of free enzymes result from 
their solubility in solution. Considerable advantages (i.e., improved catalytic activity and reusability of immobilised enzymes; binding them to a surface makes enzymes more stable and less likely to denature) are observed when converting these free (soluble) enzymes to an insoluble form. Therefore, the insolubilisation of enzymes through various immobilisation techniques has become the inevitable and effective solution to overcome these drawbacks [6]. Indeed, immobilisation has been found to be the most straightforward solution to solve the protein solubility problem $[7,8]$. Immobilisation of enzymes stabilises their structure as they attach to the support, thus retaining their activity [9]. Immobilised enzymes are stronger and more resistant to environmental changes such as heat and $\mathrm{pH}$ conditions $[10,11]$. Moreover, immobilised enzymes enable simple recovery of both the product and enzyme, several operations of enzymatic processes and various bioreactor designs [12].

Numerous reviews have extensively addressed various facets of enzyme immobilisation approaches [2,12-14]. More recently, Ba and Kumar (2017) provided a comprehensive review of developments in the use of immobilised laccases and tyrosinases and reported studies on the application of these enzymes for the treatment of chemical contaminants [15].

Many kinds of carriers have been used for the immobilisation of laccase and tyrosinase. Brugnari et al. (2018) used MANAE-agarose to immobilise laccase and then assessed its ability to degrade bisphenol A (BPA) in water [16]. In the study by Lassouane et al. (2019), laccase was immobilised on Ca-alginate beads for the degradation of bisphenol A in aqueous solutions [17]. Wen et al. (2019) reported the immobilisation of laccase on bentonite-extracted mesoporous material for the elimination of tetracycline pollutant in water [18]. In a study conducted by Costa et al. (2019), laccase was immobilised on functionalised polysulfone/carbon nanotube membranes (PSf/CNTs-Lac) [19]. The modified PSf/CNTs-Lac was used to degrade 4-methoxyphenol in water. In the study by Fathali et al. (2019), laccase was immobilised on mesoporous silica for the removal of phenols [20]. The immobilisation of tyrosinase on diatom bio-silica particles modified with 3-aminopropyl triethoxysilane (APTES) and activated with glutaraldehyde was reported by Bayramoglu et al. (2013) [21]. Tyrosinase immobilised on the modified diatom bio-silica particles was used to degrade phenolic compounds (phenyl-acetate, phenols, para-cresol) in water. Biodegradation studies were conducted for $15 \mathrm{~h}$ for both free and immobilised tyrosinase [21]. Guan et al. (2016) synthesised a biosensor by immobilising tyrosinase (Tyr) through enzyme catalytic polymerisation of poly(L-DOPA) $\left(\mathrm{PD}_{\mathrm{M}}\right)$ [22]. The $\mathrm{PD}_{\mathrm{M}}$-Tyr composite was assembled on an Au electrode and covered with Nafion to prepare the tyrosinase-modified electrode. The tyrosinase-modified electrode was used for the electrochemical detection of phenols, p-chlorophenol and o-dihydroxybenzene [22]. Kampmann et al. (2014) studied the immobilisation of tyrosinase on chitosan and silica alginate matrix capsules [23]. The developed chitosan/silica alginate tyrosinase matrix was used to remove bisphenol A in real water samples [23]. In a study by Carmango et al. (2018), an electrochemical biosensor was synthesised by immobilizing tyrosinase on a nano-diamond and potato starch matrix (Tyr-ND-PS/GCE biosensor) which was then used to detect catechol [24]. Lasmi et al. (2018) investigated the immobilisation of tyrosinase on a porous silicon (PSi) support [25]. The enzymatic activity of the immobilised tyrosinase was studied and the tyrosinase-modified Psi biosensor was used for the optical detection of pyrocatechol [25]. Antecka et al. (2018) reported on laccase immobilised on oxide materials $\left(\mathrm{TiO}_{2}-\mathrm{ZnO}_{2}, \mathrm{TiO}_{2}-\mathrm{ZnO}_{2}-\mathrm{SiO}_{2}\right)$ for the degradation of textile dyes (Reactive Black 5, Remazol Brilliant Blue R, Alizarin Red S) in wastewater [26].

This review focuses on recent techniques (2012 onwards) employed for the immobilisation of phenoloxidases (laccase and tyrosinase) for the removal of phenolic compounds in water. In particular, immobilisation by adsorption was critically assessed (physical adsorption, ionic interactions and hydrophobic interactions). The selection of suitable support materials for the immobilisation of the enzymes was also studied, as well as the effects of handling and processing, storage, heat, inhibitors and $\mathrm{pH}$ on the stability and kinetic behaviour of immobilised enzymes. 


\section{Recent Advances in Laccase and Tyrosinase Immobilisation and Insolubilisation Techniques}

Enzymes are immobilised to enhance their efficiency for practical applications [27]. Supporting enzymes on carrier materials has been found to induce properties such as easy handling, increased thermal stability and an increase in the $\mathrm{pH}$ ranges that can be tolerated [28,29]. Immobilisation can be defined as the attachment of the catalyst (i.e., enzyme) to a support. Enzymes can be supported on different organic (i.e., natural and synthetic polymers) and inorganic (natural minerals and processed materials) materials [29] (Figure 1a,b). The immobilisation methods used for the attachment of enzymes to both organic and inorganic support materials are adsorption, covalent bonding, cross-linking and entrapment/encapsulation [30].
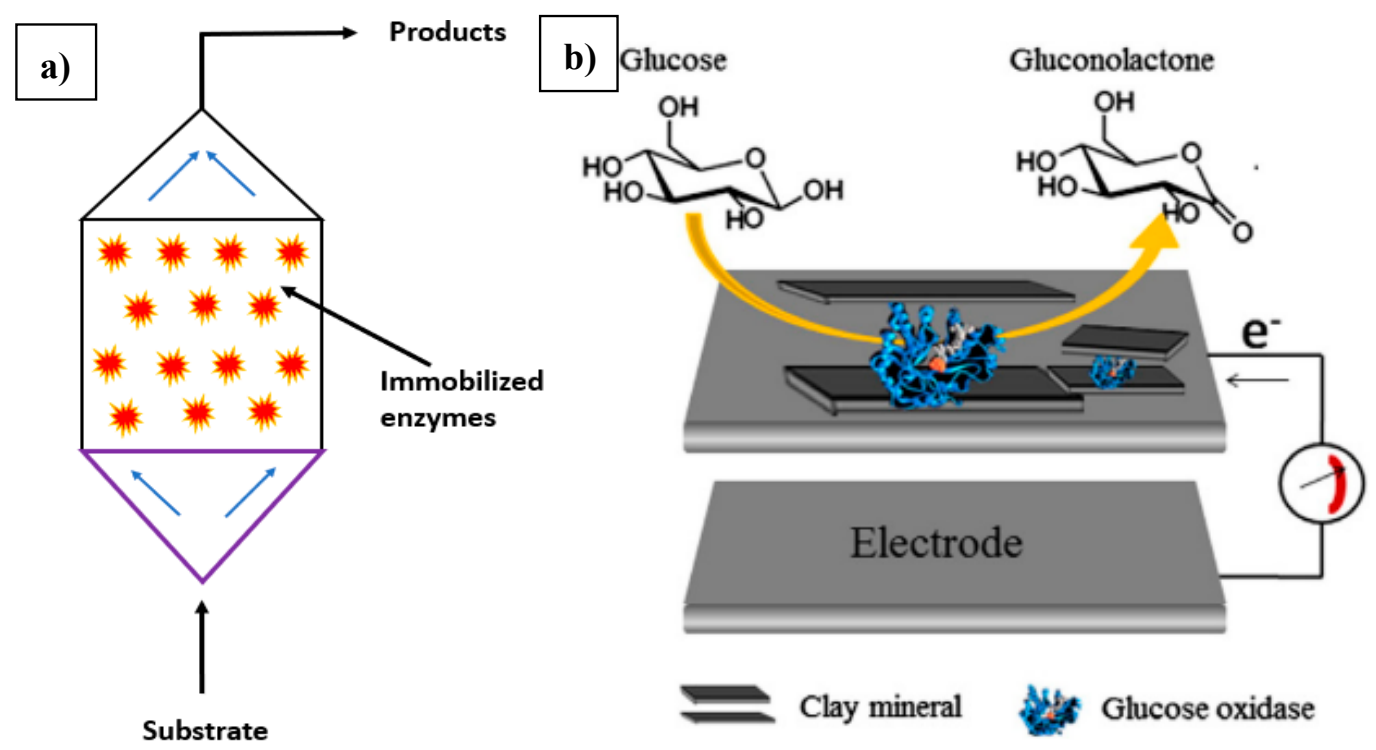

Figure 1. Enzymes immobilised on clay minerals for use as (a) biocatalysts and (b) biosensors (enzyme-based glucose biosensors) [30].

\subsection{Adsorption/Noncovalent Bonding}

Noncovalent adsorption mechanisms are subdivided into three categories, namely physical adsorption, electrostatic binding and hydrophobic adsorption; noncovalent adsorption may also occur as a combination of any of these mechanisms [31].

\subsubsection{Physical Adsorption}

In physical adsorption, the support is soaked in the enzyme solution and incubated for a certain period to allow physical adsorption to take place through van der Waals forces [28,31,32]. Van der Waals forces are frail electrostatic forces between uncharged molecules [33,34]. Lonappan et al. (2018) immobilised crude laccase on biochar (BC) microparticles (microbars) that were derived from various biochar feedstock (pine wood (BC-PW), pig manure (BC-PM) and almond shell (BC-AS)) for the removal of diclofenac in water [35]. Crude laccase was immobilised on citric-acid-functionalised biochar microparticles through physical adsorption. The binding capacity of laccase for all the biochar microparticles was improved by citric acid pretreatment. The BC-PM $\left(31.4 \pm 3.1 \mathrm{U} \mathrm{g}^{-1}\right)$ was found to be highly effective at $10 \mathrm{U} \mathrm{mL}^{-1}$ of enzyme activity, with the BC-AS being the second most effective $\left(24.3 \pm 4.8 \mathrm{U} \mathrm{g}^{-1}\right)$ and the BC-PW the least effective $\left(14.58 \pm 3.3 \mathrm{U} \mathrm{g}^{-1}\right)$. Desorption studies for all biochar-immobilised laccase fitted the pseudo-second-order model for adsorption kinetics. Immobilised laccase displayed superior storage capacity and operational stability three times higher than the free laccase. The immobilised laccase also removed close to $100 \%$ of diclofenac $\left(500 \mu \mathrm{gL}^{-1}\right)$ in water within $5 \mathrm{~h}$ [35]. 
Hyun et al. (2016) produced a laccase biosensor by immobilising laccase on porous polyaniline nanofibres (PANFs) following a three-step method that included enzyme adsorption, precipitation and cross-linking as shown in Figure 2 [36]. For the preparation of enzyme adsorption (EA), the as-spun PANFs were immersed in the laccase solution in phosphate buffer solution at $\mathrm{pH}$ 6.5. The solution was shaken at $150 \mathrm{rpm}$ for $1 \mathrm{~h}$ to allow polymerisation between the enzyme and PANFs. Preparation of cross-linked PANFs was done following the glutaraldehyde treatment approach and the enzyme adsorption cross-linking (EAC) method. Enzyme adsorption, precipitation and cross-linking (EAPC) was performed by the addition of the enzyme precipitate and cross-linkers to create cross-linking between the aggregate enzyme molecule and the PANFs. The samples prepared via the EAPC approach were demonstrated to have a highly active and stable enzyme activity owing to the precipitation and cross-linking steps when compared to the samples prepared using the EA and EAC approaches. Results revealed that $100 \%$ of their initial activity was retained when using the EAPC approach, whereas only $7.7 \%$ and $11 \%$ of the initial activity was retained when using the EA and EAC approaches, respectively. Thermal stability studies indicated that $74 \%$ of the initial activity was retained at $50{ }^{\circ} \mathrm{C}$ when using the EAPC approach, whilst the roughly $1 \%$ of the initial activity was retained at $50{ }^{\circ} \mathrm{C}$ when using the EA and EAC approaches The sensitivity values of the three enzyme electrodes produced via the EA, EAC and EAPC approaches were reported to be $20.3 \pm 5.9,26.6 \pm 5.4$ and $518 \pm 11 \mu \mathrm{A} \mathrm{mM} \mathrm{m}^{-1}$ $\mathrm{cm}^{-1}$, respectively. At the temperature of $50{ }^{\circ} \mathrm{C}$ over a period of $5 \mathrm{~h}, 80 \%$ of the initial sensitivity of the biosensor produced using the EAPC approach was retained, whilst $0 \%$ and $19 \%$ of the initial sensitivities were retained for the biosensors produced using the EA and EAC approaches. The EAPC approach was therefore recommended for environmental use in the detection of hazardous materials due to its high sensitivity and the stability of its electrochemical laccase biosensor [36]. Li et al. (2014) synthesised a phenolic biosensor based on a magnetic polydopamine-laccase-nickel-nanoparticle-loaded carbon nanofibre composite [37] Nickel-loaded carbon nanofibres (NiCNFs) were fabricated using the electrospinning method accompanied by the application of high temperature carbonisation. The NiCNFs were soaked in a solution of laccase from Trametes versicolor and acetate buffer solution at $\mathrm{pH}$ 5.5 to allow adsorption of laccase. The acetate buffer solution contained polydopamine. The reaction was conducted for $3 \mathrm{~h}$ to allow complete polymerisation of dopamine and laccase. FTIR spectrometry and cyclic voltammetry analysis showed that polydopamine-laccase-NiCNFs (PDA-Lac-NiCNFs) had outstanding biocompatibility for the immobilisation of laccase, which enabled direct electron transfer between the electrode surface and the enzyme. The immobilised laccase showed immovable, well-elucidated redox peaks. The PDA-Lac-NiCNFs biosensor displayed a sensitivity of $25 \mu \mathrm{A}$ $\mathrm{mM}^{-1} \mathrm{~cm}^{-2}$ towards catechol, a detection limit of $0.69 \mu \mathrm{A} \mathrm{mM}^{-1} \mathrm{~cm}^{-2}$ and a linear range from $1 \mu \mathrm{M}$ to $9.1 \mathrm{mM}[37]$.

A comparative study between adsorptive and covalently immobilised laccase (T. versicolor) on microporous melamine formaldehyde (Basotect) foam was conducted by Allertz et al. (2017) [38]. For the adsorptive method, Basotect (BT) was treated with hydrochloric acid and immersed in an immobilisation solution $\left(0.5 \mathrm{mg} \mathrm{mL}^{-1}\right.$ laccase, $0.2 \mathrm{M}$ sodium citrate buffer at $\left.\mathrm{pH} 4.5\right)$ for $4 \mathrm{~h}$. In covalently immobilised laccase, the BT foam was firstly functionalised with poly(ethylene-alt-maleic anhydride) (PEMA) polymer. Attenuated total reflectance Fourier transform infrared spectroscopy displayed carboxylic peaks at 1775 and $1850 \mathrm{~cm}^{-1}$, confirming the presence of PEMA on the surface of BT. The PEMA-functionalised BT were immersed in a laccase solution $\left(0.5 \mathrm{mg} \mathrm{mL}^{-1}\right.$ laccase, $0.2 \mathrm{M}$ sodium citrate buffer at $\mathrm{pH} 4.5$ ) for $4 \mathrm{~h}$ and were further treated with sodium dodecyl sulphate (SDS) to remove unbound enzymes. Laccase activity was evaluated to study the performance of different immobilisation techniques. Results revealed that physically immobilised laccase retained $4.5 \pm 8.0 \mathrm{Umg}^{-1}$ of the enzyme, covalently immobilised laccase retained $4.1 \pm 1.2 \mathrm{Umg}^{-1}$ of the enzyme which was one-quarter that of the free enzyme $\left(18.5 \pm 3.6 \mathrm{Umg}^{-1}\right)$. Covalently immobilised laccase had a slightly lower enzymatic activity due to the SDS treatment, which removed unbound laccase. The PEMA-BT-bonded laccase was used to degrade bisphenol A in contaminated water and resulted in a degradation rate above $80 \%$ [38]. 


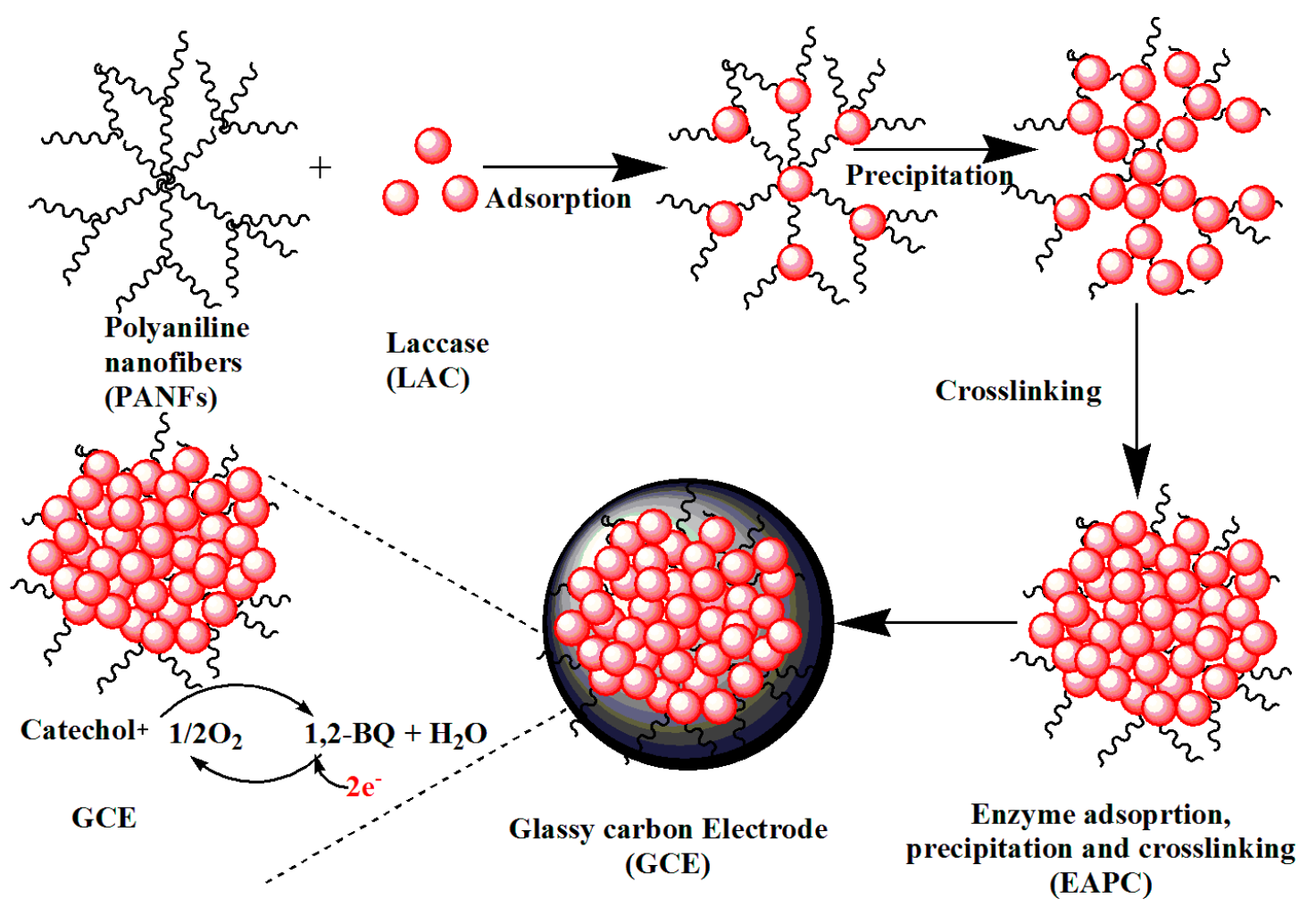

Figure 2. Enzyme immobilisation by adsorption method [36].

\subsubsection{Electrostatic Interaction/Ionic Binding}

In electrostatic/ionic binding, the enzyme is immobilised onto the oppositely charged support through strong polar and ionic interactions between the enzyme and the support $[39,40]$. Ichi-Ribault et al. (2017) immobilised laccase from Trametes versicolor on chitosan nanofibre and MWCNTs through ionic interactions in a mechanical press [41]. The effects of chitosan-immobilised laccase on the morphology and the electrocatalytic activity of the nanofibre-multiwalled carbonnanotubes (MWCNTs) were assessed, and the stability of the biocathode was determined. Adsorption of laccase (positively charged) onto chitosan nanofibre functionalised with MWCNTs is attributed to electrostatic forces of attraction, mainly donated by carboxylic acids (negatively charged) from MWCNTs. Pristine MWCNTs have a larger surface area accompanied by a larger pore size compared to chitosan-laccase-MWCNTs. The chitosan-laccase-MWCNTs have a smaller pore size due to the interconnection between chitosan nanofibre and the surface of the MWCNTs. The chitosan-laccase-MWCNTs biocathode displayed a lower catalytic current stability than pristine laccase immobilised on MWCNTs. Pristine MWCNTs are hydrophobic; therefore, immobilisation of laccase occurs through hydrophobic interaction. This means that the $\pi$ redox midpoint of laccase is very close to the electrode surface, thus providing an active oriented surface for the immobilisation of laccase on MWCNTs. On the other hand, chitosan-functionalised MWCNTs adsorbed the laccase via strong electrostatic forces of attraction between the charged laccase and the amine/carboxyl functional groups of MWCNTs resulting in the reduction of laccase activity and its electrical connectivity [41].

In a study by Gascon et al. (2014), laccase was immobilised on amino-functionalised mesoporous silica by electrostatic interaction [42]. The surface of silica was functionalised with amino groups at an acceptable $\mathrm{pH}$. Silica is known to have a negatively charged surface and therefore adsorbed the positively charged laccase. Results revealed that up to $187 \mathrm{mg} / \mathrm{g}$ of laccase was loaded onto the amino-functionalised large-pore silica. The catalytic stability of the immobilised enzyme was reported to be enhanced in ethanol. Due to the strong electrostatic interactions between the binding partners, the irreversibility of the reaction could be maintained, preventing leaching of laccase in aqueous solution. 
It was reported that immobilised enzymes retained $70 \%$ of their initial activity whilst free laccase retained only $18 \%$. The strong electrostatic forces of attraction in the biocatalyst shared the advantages of covalent bonding methods regarding catalytic stability and the non-occurrence of leaching [42].

Xia et al. (2016) reported the immobilisation of laccase on amine-functionalised magnetic $\mathrm{Fe}_{3} \mathrm{O}_{4}$ nanoparticles (NPs) coated with polyethyleneimine (PEI) to produce $\mathrm{Fe}_{3} \mathrm{O}_{4}-\mathrm{NH}_{2}$-PEINPs [43] . The PEI-modified $\mathrm{Fe}_{3} \mathrm{O}_{4}$ nanoparticles $\left(\mathrm{Fe}_{3} \mathrm{O}_{4}-\mathrm{NH}_{2}-\mathrm{PEI} \mathrm{NPs}\right)$ were chelated with $\mathrm{Cu}^{2+}$ to allow immobilisation of the laccase through metal affinity adsorption. The adsorption capacity of the $\mathrm{Fe}_{3} \mathrm{O}_{4}-\mathrm{NH}_{2}-\mathrm{PEI}-\mathrm{Cu}^{2+} \mathrm{NPs}$ was reported to be higher than that of the $\mathrm{Fe}_{3} \mathrm{O}_{4}-\mathrm{NH}_{2}-\mathrm{Cu}^{2+} \mathrm{NPs}$ (control). Higher activity recovery of the $\mathrm{Fe}_{3} \mathrm{O}_{4}-\mathrm{NH}_{2}-\mathrm{PEI}$-laccase (107.41\%) was reported compared to that of the $\mathrm{Fe}_{3} \mathrm{O}_{4}-\mathrm{NH}_{2}$-laccase (42.75\%) when the laccase concentration used for the adsorption/immobilisation of the NPs was lower than $26 \mu \mathrm{g} / \mathrm{mL}$. The corresponding specific activity of the $\mathrm{Fe}_{3} \mathrm{O}_{4}-\mathrm{NH}_{2}-\mathrm{PEI}-\mathrm{laccase}$ was found to be 101.33 times higher and that of the $\mathrm{Fe}_{3} \mathrm{O}_{4}-\mathrm{NH}_{2}$-laccase was 74.45 times higher than that of the free laccase product. Results also indicated that the $\mathrm{Fe}_{3} \mathrm{O}_{4}-\mathrm{NH}_{2}-\mathrm{PEI}$-laccase and the $\mathrm{Fe}_{3} \mathrm{O}_{4}-\mathrm{NH}_{2}$-laccase retained $60 \%$ and $48 \%$ of operational stability, respectively, in six cycles. Improvement in the enzymatic properties of both $\mathrm{Fe}_{3} \mathrm{O}_{4}-\mathrm{NH}_{2}$-PEI-laccase and $\mathrm{Fe}_{3} \mathrm{O}_{4}-\mathrm{NH}_{2}$-laccase was reported; catalytic stability and operational stability were both improved due to the strong electrostatic forces of attraction binding the support and the enzyme which minimised leaching of the enzyme. The $\mathrm{Fe}_{3} \mathrm{O}_{4}-\mathrm{NH}_{2}-\mathrm{PEI}-\mathrm{Cu}^{2+} \mathrm{NPs}$ were reported to more promising than the $\mathrm{Fe}_{3} \mathrm{O}_{4}-\mathrm{NH}_{2}-\mathrm{Cu}^{2+} \mathrm{NPs}$ for the simultaneous immobilisation and purification of laccase, indicating their potential for far-reaching wastewater treatment applications [43]. Figure 3 illustrates immobilisation of laccase through electrostatic interaction.

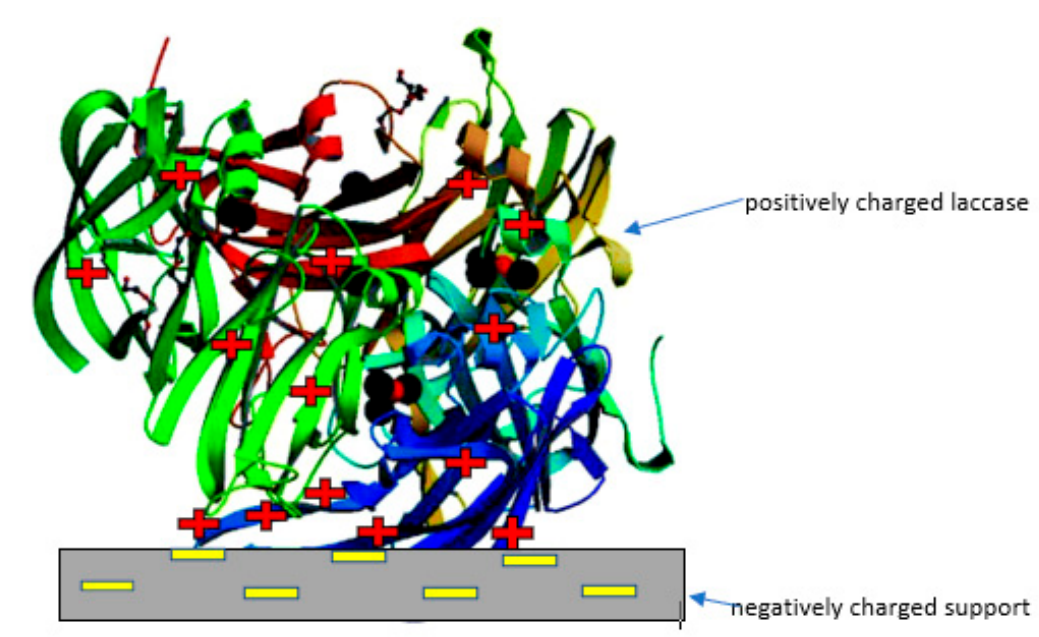

Figure 3. Schematic representation of immobilisation of laccase via electrostatic forces of attraction.

\subsubsection{Hydrophobic Adsorption}

Hydrophobic adsorption occurs due to the hydrophobic nature of the enzyme and adsorbent [44,45]. Modification of a hydrophobic carbon surface using a suspension of laccase (Trametes versicolor) and the lyophilisation agent maltodextrin was reported by Urena et al. (2016) [46]. Functionalisation of the carbon surface was characterised using quartz crystal microbalance with dissipation (QCM-D) monitoring, static contact measurements, X-ray photoelectron spectroscopy (XPS) and scanning force microscopy (SFM). The QCM-D results revealed that a rigid biomaterial layer with a thickness of a few nanometres was developed. Static contact measurements indicated that the immobilisation of laccase on hydrophobic carbon surface improved its wettability $\left(79 \pm 2^{\circ}\right)$. Spectroscopic analysis (XPS and SFM) showed that the layer formed on the surface of the carbon was a mixture of maltodextrin and laccase. The formation of the thin layer on the surface of the carbon was through hydrophobic interactions of laccase and maltodextrin with the hydrophobic carbon [46]. 
Due to their unique properties, MWCNTs are promising materials for the immobilisation of enzymes by adsorption. Immobilisation of laccase on MWCNTs via hydrophobic interaction was reported by Tavares et al. (2015) [47]. The MWCNTs were soaked in laccase solution and continuously stirred, allowing hydrophobic contact between the enzyme and the MWCNTs (support). The laccase-MWCNTs were characterised by FTIR spectroscopy and SEM. The SEM analysis showed that the addition of laccase covered the MWCNTs with a layer of distinct material. Transmission electron microscopy (TEM) analysis of the laccase-MWCNT system displayed a globular structure of laccase which extended all over the side walls of the carbon nanotubes. The FTIR analysis confirmed the existence of laccase in the MWNTs. Studies on the kinetic behaviour and the operational, storage and thermal stability were conducted to investigate the performance of the laccase-MWCNT system. The Michaelis-Menten constant $\left(K_{\mathrm{m}}\right)$ was found to be higher for laccase-MWCNTs $\left(K_{\mathrm{m}}=\right.$ $1920 \mathrm{mM} / \mathrm{mm})$ compared to that of the free laccase $\left(K_{\mathrm{m}}=00068 \mathrm{mMmm}^{-1}\right)$ due to the decrease in randomness of the reaction system. Operational studies revealed that the laccase-MWCNTs retained $67 \%$ of the enzyme's initial activity in nine cycles of reuse, compared to $90 \%$ of the free enzyme; this was attributed to the leaching of the enzyme as it was not covalently bonded to the MWCNTs. A decrease in the thermal stability of the immobilised laccase was reported, which was also attributed to the desorbed enzyme from MWCNTs. Storage stability experiments indicated that the laccase-MWCNT system and the free enzyme both retained $60 \%$ of the enzyme's activity after 34 days of incubation at $4{ }^{\circ} \mathrm{C}[47]$.

In a study by Han et al. (2019), laccase was immobilised on carbon nanotubes (CNTs), graphene nanosheets (GNs) and solid carbon spheres (SCSs) to allow bio-electrocatalytic reduction of oxygen [48]. Laccase was immobilised on CNTs, GNs and SCSs through hydrophobic interactions of aromatic residues of $\mathrm{T} 1$ close to $\mathrm{Cu}$ ions of laccase and through $\pi$-conjugated carbonaceous surfaces of CNTs, GNs and SCSs. A comparison was made of laccase immobilised on CNTs, GNs and SCSs. It was reported that ethanol-assisted hydrophobic adsorption of laccase on single-walled carbon nanotubes (SWCNTs) gave the highest bio-electrocatalytic current response. Kinetics of heterogeneous electron transfer during oxygen reduction was quantified in terms of the apparent electron transfer rate constant $\left(k^{0 \prime}\right)$. Direct electron transfer (DET) experiments showed that carbon nanomaterials with smaller dimensions or higher surface curvature had a larger electron transfer rate constant $\left(k^{0 \prime}\right)$. For example, $k^{0 \prime}$ was calculated and found to be $1.92 \mathrm{~s}^{-1}$ for laccase adsorbed to single-walled CNTs with a diameter (d) of $\sim 1.5 \mathrm{~nm}, 1.05 \mathrm{~s}^{-1}$ for laccase adsorbed to double-walled CNTs with $\mathrm{d}=2-4 \mathrm{~nm}, 1.52 \mathrm{~s}^{-1}$ for laccase adsorbed to thinner multi-walled CNTs with $\mathrm{d}=8-15 \mathrm{~nm}$ and $0.62 \mathrm{~s}^{-1}$ for laccase adsorbed to thicker multi-walled CNTs with $\mathrm{d}=20-30 \mathrm{~nm}$. For laccase adsorbed to graphene nanosheets, $k^{0 \prime}$ was found to be $0.63 \mathrm{~s}^{-1}$. Thedifference in direct electron transfer kinetics is attributed to the surface properties of the support (oxygen-containing groups, surface curvature) and the conductivity of the nanomaterials. Laccase immobilised on SCSs $(\mathrm{d}>200 \mathrm{~nm})$ showed no catalytic activity. It was found that the catalytic current response is enhanced by higher surface curvature relative to the size of the laccase molecule, and the best bio-electrocatalytic performance was reported with laccase physically adsorbed on SWCNTs [48]. Figure 4 demonstrates laccase enzyme immobilised on hydrocarbons (attached to carbon-based supports) through its hydrophobic pocket. 


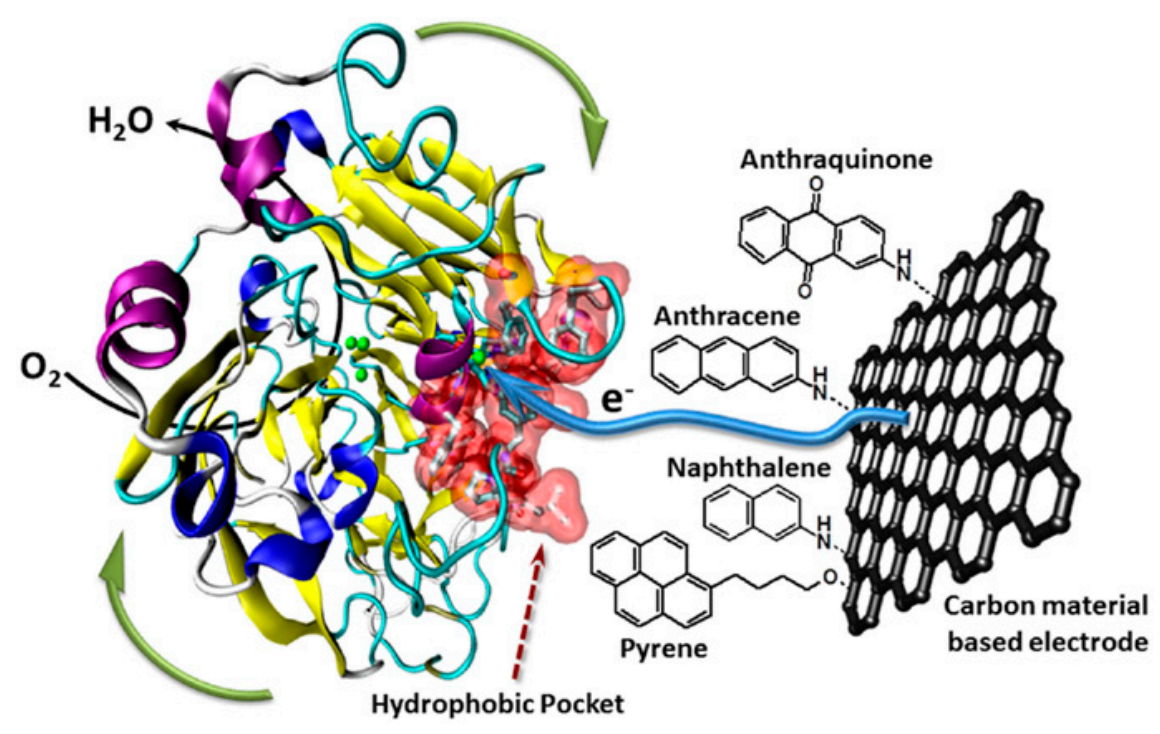

Figure 4. Laccase immobilised through its hydrophobic pocket with hydrocarbons that are attached to carbon-based support [49].

\subsection{Covalent Bonding}

Immobilisation of enzymes by covalent bonding forms stable complexes between the enzyme's functional groups and the support matrix [50-52]. The enzyme's functional groups utilised in covalent bonding include the amino, phenolic, carboxylic, thiol, sulfhydryl, hydroxyl, imidazole and indole groups [52,53]. Binding of the enzyme onto the support is achieved by the activation of the surface using cross-linkers such as N-hydroxysuccinimide, glutaraldehyde and 1-ethyl-3-(3-dimethylaminopropyl)carbodiimide hydrochloride, allowing the enzyme to covalently bond to the activated support [22].

In a study carried out by Abdollahi et al. (2017), magnetic nanoparticles (MNPs) were synthesised and coated with silica [54]. The coated MNPs were then functionalised with 3-aminopropyltriethoxysilane and immersed in cyanuric chloride and tetrahydrofuran solution to develop cyanuric-chloride-functionalised magnetic nanoparticles (Cy-MNPs). By adding these Cy-MNPs to a freshly prepared tyrosinase solution and shaking the mixture, the tyrosinase enzyme was then covalently immobilised, as shown in Figure 5. The tyrosinase-immobilised magnetic nanoparticles (tyrosinase-MNPs) were characterised using FTIR spectroscopy and energy-dispersive X-ray (EDX) spectroscopy. Both FTIR and EDX data showed that the tyrosinase was successfully covalently bonded to the Cy-MNPs. The TEM images showed that tyrosinase-MNPs had a semi-spherical structure with an average size of $17 \mathrm{~nm}$. The developed tyrosinase-immobilised magnetic nanoparticles were shown to have a high catalytic activity even after treatment under varied $\mathrm{pH}$ and temperature conditions. The characteristics of the tyrosinase-MNPs seemed to indicate that they might be suitable for degrading phenolic compounds in water due to their ability to remove $100 \mathrm{mg} / \mathrm{L}$ of phenols in water within $2 \mathrm{~h}$ [54]. 


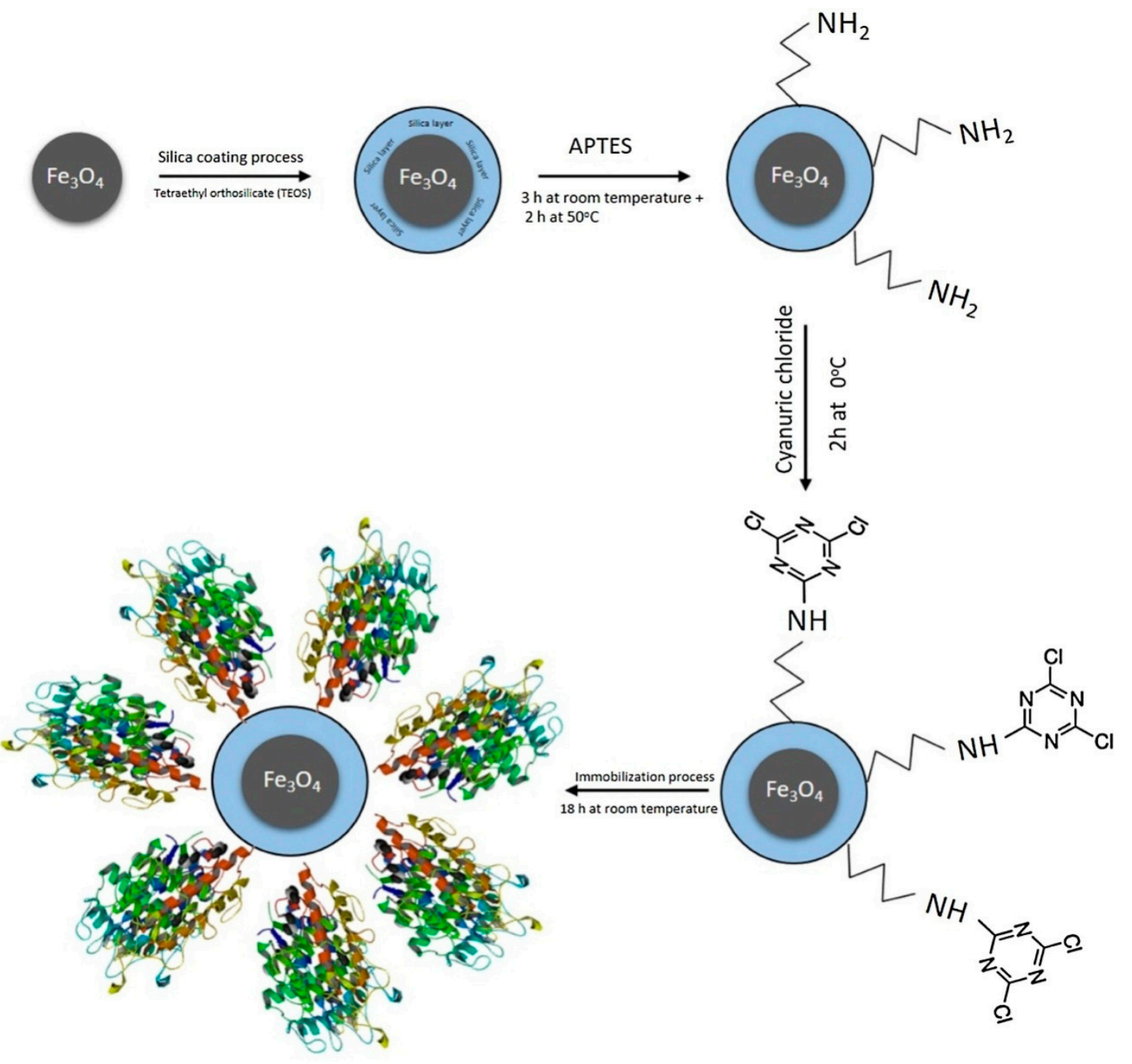

Figure 5. Enzyme immobilisation on the modified magnetic nanoparticle by covalent bonding method [54].

Recently, Koloti et al. (2018) reported the immobilisation of the laccase enzyme on hyperbranched polyethyleneimine/poly(ethersulfone) (HPEI/PES) electrospun nanofibre membranes [55]. The enzyme from Rhus vernicifera was covalently bonded to the HPEI/PES nanofibres through the abundant amine groups on the HPEI. Glutaraldehyde was used to cross-link the laccase and HPEI/PES nanofibre mats. The laccase-immobilised HPEI/PES nanofibres were characterised using SEM coupled with energy-dispersive X-ray (SEM-EDX), ATR-FTIR, ultraviolent-visible spectroscopy and correlative light and electron microscopy (CLEM). The SEM analysis indicated that the HPEI/PES nanofibres had an average fibre diameter of $354 \pm 37 \mathrm{~nm}$, whilst the laccase-modified HPEI/PES nanofibres $(4 \mathrm{mg} / \mathrm{mL}$ of laccase) had an average fibre diameter of $580 \pm 82 \mathrm{~nm}$. The existence of $\mathrm{Cu}$ cations was confirmed by EDX analysis, which confirmed the presence of the laccase enzyme. Contact angle, pure water flux measurement and analysis of bisphenol A (BPA) rejection were conducted to investigate the performance of the enzyme-modified HPEI/PES nanofibre membrane. The analysis of contact angles $\left(50-53^{\circ}\right)$ showed that the laccase-modified HPEI/PES nanofibre membranes were hydrophilic, the permeate water flux was reported to be $7.07 \pm 5.54 \mathrm{~L} \cdot \mathrm{m}^{-2} \cdot \mathrm{h}^{-1}$ and BPA rejection of $89.9 \%$ was recorded; BPA rejection of up to $79 \%$ was achieved even after four filtration cycles. Recyclability studies showed that the laccase-modified membrane could be reused. It was also reported that this study contributed to membranes scope of work which determines the application of hyperbranched polymers in water treatment [55]. 
In a study conducted by Harir et al. (2018), tyrosinase was immobilised on nylon nanofibre membranes [56]. The tyrosinase produced by Sahara soil Actinobacteria was covalently immobilised on the nylon nanofibre mats. To allow covalent bonding, the hydrolysed nylon nanofibres were rinsed with a potassium phosphate buffer solution at $\mathrm{pH} 7$ and reacted with glutaraldehyde, which acted as a cross-linker to covalently bond the tyrosinase to the nylon nanofibrous support. Results revealed that due to its biochemical characteristics, the enzyme was able to oxidase L-3,4-dihydroxyphenylalanine (L-DOPA) (substrate). Tyrosinase showed stability when used in different organic solvents that are miscible in water without activation by reducing agents, and its activity was also unaltered by the presence of $\mathrm{NaCl}$; instead, its activity was enhanced by other cations such as calcium. The use of $1 \%$ glutaraldehyde stabilised the immobilisation of tyrosinase on nylon nanofibre membranes with a catalytic activity of up to $82 \%$ being recorded. Based on the exclusive advantages of the developed nylon-tyrosinase immobilised nanofibre membrane, the material was recommended to be ideal for the removal of phenolic compounds in water [56].

Laccase from Pleurotus ostreatus (mushroom) was covalently bonded on polyacrylonitrile (PAN) nanofibre membrane through amide bond formation based on the ethanol/ $\mathrm{HCl}$ method by $\mathrm{Xu}$ and co-workers (2013) [57]. The PAN-laccase nanofibre membrane was used to remove 2,4,6-trichlorophenol (TCP) from water. The scanning electron microscopy (SEM) images showed that the laccase was attached to the surface of the nanofibre mats. The immobilised laccase enzyme on the nanofibre membrane retained $72 \%$ of the catalytic activity of free laccase, whilst the PAN-laccase nanofibre membrane retained $60 \%$ of its initial catalytic activity after 10 operating cycles. Storage stability studies indicated that the PAN-laccase nanofibre membrane retained $92 \%$ of its initial activity after 18 days of storage, whereas free laccase maintained $20 \%$ of its catalytic activity. The PAN-laccase nanofibre membrane displayed a high TCP removal efficiency, reaching up to $85 \%$ degradation under optimum conditions, illustrating a new approach to the degradation of pollutants in water [57].

\subsection{Cross-Linking}

This method of immobilisation depends only on the enzyme and not its support [58]. The enzymes are chemically joined to each other through reactive sites and the use of intermolecular cross-linkages such as glutaraldehyde to prepare a large three-dimensional complex $[55,59,60]$.

The potential of cross-linked enzyme aggregates (CLEAs) for wastewater treatment has been explored. In a study by Fathali et al. (2019), laccase from T. versicolor was cross-linked to form laccase aggregates [20]. The laccase aggregates were further entrapped in mesoporous silica to form entrapped cross-linked enzyme aggregates (E-CLEAs). The modified E-CLEA was used to remove phenols in water. To investigate the removal of phenols, the study was conducted for $40 \mathrm{~min}$, whereby the protein content of E-CLEA used was estimated to be $0.32 \mathrm{mg}$, the initial concentration of phenols was $37.645 \mathrm{mgL}^{-1}$ and the solution was continually stirred in acetic buffer solution at $\mathrm{pH} 4.5$. Results indicated that the cross-linked catalyst removed $0.251 \mathrm{mgL}^{-1}$ of phenols per minute per $\mathrm{mg}$ $\left(\mathrm{min}-1 \cdot \mathrm{mg}^{-1}\right)$ whilst the free enzyme $\left(10 \mathrm{Umg}^{-1}\right)$ equivalent to $1 \mathrm{mg}$ of E-CLEA removed $0.03 \mathrm{mgL}^{-1}$ of phenols/min/mg, which showed that the cross-linked enzyme (E-CLEA) had a high phenol removal efficiency Furthermore, good reusability was reported, as the cross-linked enzyme retained $79 \%$ of its initial activity after 20 successive operating cycles [20].

Magnetic cross-linked laccase aggregates were used as a bioremediation tool by Kumar et al. (2014) for the decolourisation of dyes in water [61]. Glutaraldehyde was used to produce these magnetic cross-linked enzyme aggregates (mCLEAs). The amino-functionalised magnetic nanoparticles were bonded to CLEA-laccase to improve the mechanical stability of the CLEAs; the activity recovery obtained using mCLEAs was roughly $32 \%$, accompanied by improved thermal and operational stability. Kinetic experiments showed that the catalytic efficiency of the enzyme in the CLEA and mCLEA formations changed significantly; the catalytic efficiency of the mCLEA-laccase was eight-fold higher than that of the free enzyme, and the initial laccase activity was preserved over four iterative cycles. Results also stated that $0.2 \mathrm{U} / \mathrm{mL}$ of CMLEA decoloured $61-69 \%$ of $50 \mathrm{mg} / \mathrm{L}$ Malachite 
Green, Reactive Black and Remazol Brilliant Blue R at $20^{\circ} \mathrm{C}$ and $\mathrm{pH}$ 7.0.Efficient decolourisation by mCLEAs was achieved by degrading Remazol Brilliant blue R for $10 \mathrm{~h}$, whereby $>90 \%$ of the dye was removed [61].

According to Yang et al. (2016), laccase from the white-rot fungus Cerrena was cross-linked to form cross-linked enzyme aggregates (CLEAs) for decolourising Remazol Brilliant Blue R (RBBR) dye in water [62]. Glutaraldehyde was used as a cross-linker, which was precipitated with ammonium sulphate, thus developing CLEAs. With the use of $30 \mathrm{mM}$ of glutaraldehyde for $3 \mathrm{~h}$ these laccase-CLEAs exhibited a catalytic activity of $68.1 \%$ at room temperature and $\mathrm{pH} 8$. Results indicated that immobilised Cerrena-laccase had improved lenience to metal ions $\left(\mathrm{Na}^{+}, \mathrm{Cu}^{2+}, \mathrm{Pb}^{2+}\right)$ organic solvents (methanol, dimethylformamide, acetone) and to $\mathrm{NaCl}$, as compared to the free laccase. Moreover, laccase-CLEA demonstrated high efficiency and velocity towards the removal of RBBR dye in water $(84 \%$ of $40 \mathrm{mM}$ RBBR removed within $2 \mathrm{~h}$ ) in the presence of $\mathrm{NaCl}$ compared to free laccase (76\% of $40 \mathrm{mM}$ RBBR removed within $2 \mathrm{~h}$ ) [62].

In a study conducted by Pavinatto et al. (2018), an ultrasensitive biosensor for the electrochemical detection of $17 \alpha$-ethinyl estradiol was produced via a one-step route using poly(vinylpyrrolidone)/chitosan/reduced graphene oxide (PVP/Chi/rGO)nanofibres coated with the laccase enzyme from Trametes versicolor [63]. For activating the hydroxyl $(-\mathrm{OH})$ and amine $\left(-\mathrm{NH}_{2}\right)$ functional groups, the cross-linking solution glutaraldehyde was added to the PVP/Chi/Rgo nanofibers and then coated with laccase enzyme. These hybrid nanofibers were then deposited on a fluorine-doped tin oxide electrode and showed good electrochemical properties and suitability to assemble laccase. It was reported that the PVP/Chi/rGO-laccase modified electrode had a very low limit of detection $(0.15 \mathrm{pmol} / \mathrm{L})$ for $17 \alpha$-ethinyl estradiol female synthetic hormone. This biosensor also showed exceptional reproducibility with a relative standard deviation (RSD) of $8.44 \%$ and $4.29 \%$ to inter- and intra-electrode and was found to be selective for EE2 detection in the presence of numerous inferring compounds; therefore, it was recommended for environmental applications [63]. Figure 6 illustrates the immobilisation of enzymes through cross-linking method.

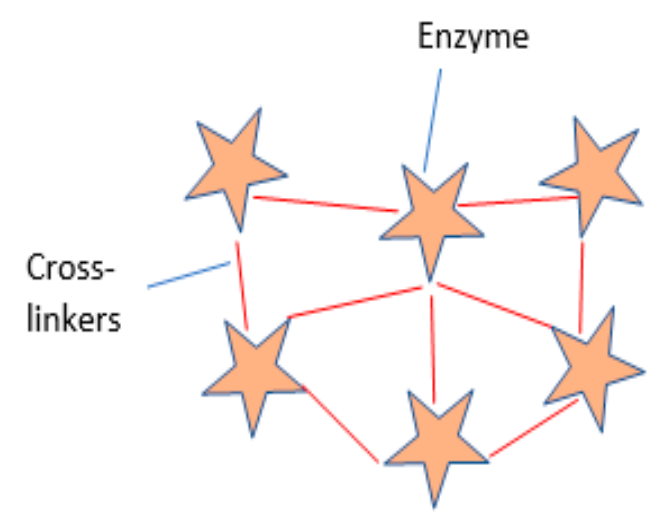

Figure 6. Enzyme immobilisation by cross-linking method.

\subsection{Entrapment/Encapsulation}

Immobilisation by entrapment depends on the gel matrix (support) which holds the enzyme [64]. Encapsulated enzymes are like entrapped enzymes except that in encapsulation the enzyme is wrapped in a semipermeable membrane [65]. The support acts as a barrier to mass transfer, thus retaining the enzymes but allowing substrate and products to pass through. The difference between the entrapment/encapsulation immobilisation technique and the adsorption, covalent and cross-linking methods is that the free movement of the enzyme is restricted by a gel lattice or semipermeable membrane [65].

Laccase from T. versicolor was immobilised on polyacrylonitrile-biochar (PAN-biochar) by Taheranet al. (2017), and the produced biocatalyst was used for the removal of chlortetracycline in 
water [66]. Laccase was entrapped in the PAN-biochar by immersing the composite membrane in an aqueous solution of hydroxylamine hydrochloride at $\mathrm{pH} 6$ and $70 \pm 1{ }^{\circ} \mathrm{C}$ for $2 \mathrm{~h}$. Amidoxime linkages were formed on the surface of the PAN-biochar, and the composite was immersed in a laccase solution with $\mathrm{pH} 4.5$ acetate buffer solution to allow the entrapment of the enzyme. Results revealed that the laccase entrapped in the PAN-biochar had better storage, temperature and $\mathrm{pH}$ stability in relation to the free enzyme. The immobilised laccase also retained above $50 \%$ of its initial activity after seven cycles of 2,2-azino-bis(3-ethylbenzothiazoline-6-sulphonic acid)(ABTS) oxidation. The PAN-biochar immobilised laccase was also shown to degrade chlortetracycline in a continuous mode with removal efficiencies of $58.3 \%, 40.7 \%$ and $22.6 \%$ at flux rates of 1,2 and $3 \mathrm{~mL} / \mathrm{h} / \mathrm{cm}^{2}$, respectively [66].

In a study by Mansoret al. (2016), the optimisation of laccase in situ entrapment in mesoporous silica microparticles (MSMs) was investigated [67]. An experimental response surface methodology (RSM) was designed to establish a relationship between the optimal synthesis conditions and the independent synthesis variables (ISVs). The ISVs comprising of the water/tetraethyl orthosilicate $\left(\mathrm{H}_{2} \mathrm{O} /\right.$ TEOS) molar ratio, triethylamine (TEA) loading, hydrochloric acid $(\mathrm{HCl})$ loading, and laccase loading were assessed in terms of the laccase specific catalytic activity response as the dependent variable. Optimisation results indicated that the optimal ISV for $\mathrm{H}_{2} \mathrm{O} /$ TEOS was 5.44. For TEA it was $0.39 \times 10^{-3} \mathrm{~mol}$, for $\mathrm{HCl}$ it was $2.52 \times 10^{-6}$ and for laccase it was $3.3 \mathrm{mg} / \mathrm{mL}$. A correlation between catalytic activity response and ISV was determined by a coefficient $\left(R^{2}\right)$ value of 0.89 . It was reported that the laccase-entrapped mesoporous silica microparticles had outstanding reusability capacity, reaching up to $90 \%$ of the enzyme's activity in 10 cycles towards 2,2-azino-bis (3-ethylbenzothiazoline-6-sulphonic acid). The LMS also had a high potential for the removal of phenolic contaminants in water [67].

The use of cyclodextrins has been suggested as alternative support for enzyme immobilisation processes. The effect of cyclodextrin $(\gamma-C D)$ use on the enzymatic activity of laccase following immobilisation of this enzyme on poly( $\varepsilon$-caprolactone) (PCL) nanofibre membranes was studied by Canbolat et al. (2017) [68]. Immobilisation of laccase from T. versicolor on nanofibre structures was prepared considering three methods, with and without the addition of $\gamma$-CD. For the first technique, a solution of PCL and laccase was electrospun to produce enzymes encapsulated by nanofibre mats. In the second technique, the enzyme (laccase) and $\gamma-\mathrm{CD}$ were added to the PCL polymer solution prepared initially and mixed; this mixture was encapsulated in the nanofibre structure by electrospinning. In the third technique, purified laccase and a mixture of laccase and $\gamma$-CD were sandwiched between the nanofibre layers to produce a laccase- $\gamma-\mathrm{CD}$ complex, and then it was immobilised on the nanofibre mats by both encapsulation method (electrospinning of the laccase- $\gamma-C D$ complex containing PCL solution) and by entrapment method (sandwiching laccase- $\gamma$-CD complex into nanofibre sheets). The produced structures were characterised using SEM, FTIR and XRD (X-ray diffraction). The SEM and FTIR results revealed the formation of laccase- $\gamma-\mathrm{CD}$ interactions forming different types of complexes. The authors found that the use of cyclodextrin has a positive effect on the activity of the enzyme and improves its stability. The enzyme applied with cyclodextrin displayed activation after complex creation without the denaturing of the enzyme. Laccase activity tests indicated that immobilisation by the encapsulation method produced improved enzyme activity as compared to the entrapment (layering) method. The characteristics of the $\gamma-C D$ biocatalyst showed it to be a viable nanomaterial for the elimination of phenolic pollutants in water [68].

MWCNTs moulded with laccase electrospun fibrous membranes (LCEFM) were developed by Dai et al. (2016) for the removal of bisphenol in water [69]. The MWCNT-LCEFM nanofibres were fabricated via the in situ electrospinning method. In preparing the polymer solution, the laccase was first mixed with poly(D,L-lactide) (PDLLA) to stabilise the enzyme and then added to the MWCNTs. Results showed that the active laccase was encapsulated within the fibres of the homogeneous MWCNT-LCEFM depicted from the edge of the pores. Mechanical tensile strength and specific surface area of MWCNT-LCEFM were improved by approximately three times when $1.5 \mathrm{wt} \%$ of PDLLA was added in comparison to those of LCEFM. Also, the MWCNT-LCEFM nanofibres showed a higher catalytic activity $(89.9 \%)$ with improved storage and operational capacity compared to 
LCEFM. Triclosan, bisphenol A and 2,4-dichlorophenol were degraded using MWCNT-LCEFM, and it was stated that the adsorption efficiency of the modified nanofibre membrane for bisphenol A and 2,4-dichlorophenolwas improved by $50 \%$. Up to $99.7 \% \pm 0.02 \%, 95.5 \% \pm 0.46 \%$ and $92.6 \% \pm 0.74 \%$ of the triclosan, bisphenol A and 2,4-dichlorophenol were removed, respectively, by the MWCNT-LCEFM, with degradation efficiencies recorded at $85.6 \% \pm 1.5 \%, 90.5 \% \pm 1.1 \%$ and $81.7 \% \pm 1.9 \%$, respectively, thus indicating their practical potential for the treatment of emerging organic pollutants (triclosan, bisphenol A, 2,4-dichlorophenol) in wastewater [69].

Zhang et al. (2018) encapsulated laccase from T. versicolor in copper alginate beads for the elimination of 2,4-dichlorophenol in contaminated water [70]. In encapsulation of laccase, sodium alginate solution $(1.0 \% \mathrm{w} / \mathrm{v})$ was added to a solution consisting of $\mathrm{CuCl}_{2}$ and laccase. FTIR spectrometry showed that laccase was successfully immobilised in copper alginate beads. The laccase encapsulated in copper alginate beads exhibited outstanding $\mathrm{pH}$ stability at $\mathrm{pH} 2.2(87.6 \%)$ and 8 $(91.3 \%)$, whilst free laccase maintained $9.5 \%$ and $23.2 \%$ of its initial activity at $\mathrm{pH} 2.2$ and 8 , respectively, indicating that immobilizing enzymes enhance their stability over a wide $\mathrm{pH}$ range. Thermal stability studies conducted between $20-60^{\circ} \mathrm{C}$ showed that both laccase encapsulated in copper alginate beads and free laccase had their maximum activity at $40{ }^{\circ} \mathrm{C}$. In addition, thermal stability was reduced between $40-60^{\circ} \mathrm{C}$, where the encapsulated laccase enzyme reduced at a lower rate than free laccase, indicating that immobilised laccase enzymes can withstand high temperatures. It was also reported that laccase encapsulated in copper alginate beadseliminated $94.6 \%$ of 2,4-dichlorophenol, whereasfree laccase eliminated only $42.4 \%$ of the organic pollutant(2,4-dichlorophenol) in $10 \mathrm{~h}$. Reusability analysis for laccase entrapped copper alginate beads revealed that elimination of 2,4-dichlorophenol was reduced from $94.6 \%$ to $80.4 \%$ in 10 cycles implying that this biocatalyst can be used for phenolic elimination in practical wastewater applications [70].

In a study conducted by Gill et al. (2018), laccase from Coriolus hirsutus was encapsulated in alginate, alginate-silica hybrids and sol-gel silica [71]. For the hybridisation of alginate with silica, two methods were carried out. The first method involved the preparation of calcium alginate beads, which were obtained within $5 \mathrm{~min}$ and added to a solution of silica precursor (tetraethyl orthosilicate (TEOS)) and hexane. The second method included the incubation of calcium alginate beads in pre-hydrolysed sol-gel silica prepared from vigorous stirring and ultrasonication of hydrochloric acid, TEOS and water. Results revealed that using the second method, namely the addition of silica into alginate, resulted in an improvement of $70 \%$ in the encapsulation efficiency (EE) for the laccase compared to that for the alginate without silica (59\%). When the laccase was encapsulated in sol-gel silica, a $90 \%$ increase in the EE was recorded, and the catalytic activity of the enzyme was shown to be enhanced. Laccase encapsulated in the sol-gel matrices and alginate also improved the catalytic efficiency of the enzyme, with $k_{\text {cat }}$ of 63.7 and $89.9 \mathrm{~min}^{-1}$, respectively, in comparison to that of the free laccase $\left(k_{\text {cat }}=56.9 \mathrm{~min}^{-1}\right)$. Laccase encapsulated in sol-gel silica was shown to have a better reusability, with $82.7 \%$ residual enzyme activity after five reaction cycles, whilst laccase encapsulated in alginate retained $71 \%$ of the enzymes' activity. Storage studies for the laccase immobilised in alginate, alginate silica prepared by the second method and sol-gel silica exhibited stability at $4{ }^{\circ} \mathrm{C}$ without any enzyme loss after 6 weeks of storage [71]. Figure 7 shows the immobilisation of enzymes via the entrapment/encapsulation method. 


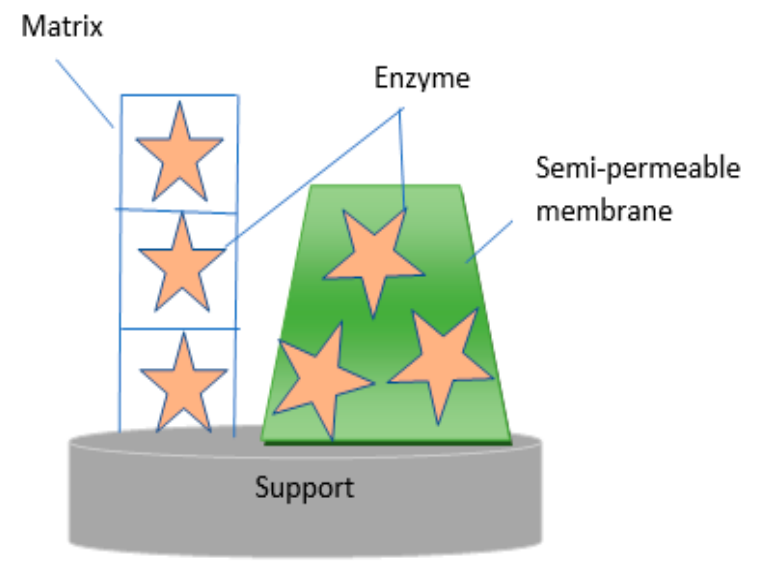

Figure 7. Enzyme immobilisation by entrapment/encapsulation method.

\subsection{Support Matrices for Immobilisation of Laccases and Tyrosinases}

In the section below, we review the different support matrices that have been used in various studies for the immobilisation of enzymes.

\subsubsection{CNTs as Support for Enzymes}

Due to their mechanical properties and thermal and chemical stability, carbon nanotubes (CNTs) have been used as biological carriers. In a study conducted by Oliveira et al. (2018), CNTs were used as supports for a fungal enzymatic extract containing lignin peroxidase (LiP) [72]. This system was used in the enzymatic degradation of Remazol Brilliant Blue R (RBBR) dye. In this study, the authors specifically investigated the lignin peroxidase catalytic efficiency, stability and reusability after the dye removal. It was found that the purified enzymes attached to the CNTs had high enzymatic specific activity as compared to the free enzymes. Enzymes extracted from Pleurotus ostreatus (PLO9) showed an 18-fold increase in specific activity compared to that of the free enzyme, while the Ganoderma lucidum (GRM117) fungal enzymatic extracts showed an activity that was 27 times higher than that of the free enzymes. This was assigned to the fact that CNTs are stable in extreme conditions. Due to their large surface area, they enhance the enzyme loading capacity, thus resulting in ten time's higher enzymatic catalytic activity than that of the free enzyme. Reusability studies showed that the immobilised enzymes had the capacity to decolourise the dye on reuse, whilst the free enzymes did not show any catalytic activity in the decolourisation of the dye at 10 and $30 \mathrm{mgL}^{-1}$. However, during the reusability studies, it was found that CNTs became saturated by dyes overtime, and thus these need to be discarded overtime. The high catalytic efficiency revealed that the enzyme-immobilised CNTs are capable of removing dyes in industrial applications [72].

In a similar study, Xu et al. (2015) attached the laccase enzyme on PVA/chitosan/MWCNTs [73]. The PVA/chitosan/MWCNTs were electrospun on an aluminium foil; these fibres were then activated using glutaraldehyde, and subsequently the laccase enzyme was covalently immobilised on the surface of the PVA/chitosan/MWCNTs. Enzyme loading capacity and retention of activity of the immobilised laccase were higher on nanofibre membranes with MWCNTs than on those without MWCNTs. The PVA/chitosan/MWCNT-immobilised laccase membranes were then applied in the removal of diclofenac. Temperature, $\mathrm{pH}$ and reaction time were found to be the main factors which contributed to the diclofenac removal rate. It was found that the diclofenac removal efficiency was higher with laccase PVA/chitosan/MWCNTs (100\% removal) as compared to laccase PVA/chitosan (84.9\% removal). The presence of the MWCNTs was found to increase/improve the electron transfer between the enzyme and the substrate molecules, thus enhancing the enzymatic activity of the laccase. Diclofenac removal efficiency by laccase PVA/chitosan/MWCNTs showed that the biocatalyst can be used as a new approach for the degradation of organic pollutants in the environment [73]. 
Carbon-based nanotube membranes were fabricated through single-side deposition on poly(vinylidene fluoride) (PVDF) membranes in a study by Ji et al. (2016) [74]. Subsequently, the membrane was cross-linked with PVA and glutaraldehyde. Laccase enzyme was then immobilised via physical and chemical adsorption. This enzymatic membrane reactor (EMR) was used to remove selected micro-organic pollutants such as diclofenac (DCF), ibuprofen (IBF), bisphenol-A(BPA), clofibric acid (CA) and carbamazepine (CBZ). The dead-end filtration cells were used to carry out adsorption studies of these pollutants. The virgin PVDF membranes were found to remove less than $1 \%$ of the pollutants after $48 \mathrm{~h}$, while the PVDF-CNTs removed between $20-30 \%$ due to the presence of CNTs with a large surface area; hydrophobicity interaction between CNTs and organic compounds, hydrogen bonding and $\pi-\pi$ interactions were contributing factors. After immobilisation of free laccase on the system, $90 \%$ of BPA and $75 \%$ of diclofenac were removed. Considerable removal was reported for the other micropollutants, i.e., $68 \%, 49 \%$ and $46 \%$ of ibuprofen, carbamazepine and clofibric acid were removed, respectively. At higher CNT loading, i.e., $25 \mathrm{mg} / \mathrm{g}$ CNT coated biocatalytic membrane, it was found that the BPA removal rate was increased by $6 \%$, which showed that at high loading rate there was undesired overcrowding of the laccase enzyme. Only a $10 \%$ decrease in BPA and diclofenac removal efficiencies was observed after four degradation cycles; however, for the other recalcitrant compounds, a remarkable decrease in their removal after four cycles was reported. This was attributed to the fact that during degradation of these compounds there would be oxidative condensation reactions with phenoxy radicals and CNTs. These reactions might lead to the formation of oligomers or polymers that can accumulate on CNTs, hindering cross-coupling reactions with phenolic compounds. Overall, these findings indicated that CNT-based biocatalysts can be used for industrial applications in membrane-based wastewater treatment [74].

\subsubsection{Cross-Linked Enzyme Aggregates as Supports}

Cross-linked enzyme aggregates (CLEAs) are extremely resistant to organic solvents, high $\mathrm{pH}$ and temperature [75]. Cross-linked enzyme aggregates also have great stability under operating conditions. In a study conducted by $\mathrm{Xu}$ and Yang (2013), mushroom tyrosinase was immobilised as a cross-linked enzyme aggregate (CLEA) and used for the enzymatic treatment of phenolic wastewater [75]. The CLEA was prepared by extracting the tyrosinase from mushrooms and precipitating it in ammonium sulphate and subsequently cross-linking it with glutaraldehyde as shown in Figure 8. Furthermore, the CLEAs were then coated with alginate gel to form calcium CLEA alginate beads. This immobilisation method has been found to be inexpensive and easy to prepare, and it results in highly stable and recyclable catalysts. The tyrosinase CLEA (50 mg immobilised enzyme) was used in the complete dephenolisation of p-cresol, p-chlorophenol and phenol. Up to $98.9 \%$ of BPA was found to be removed with the same amount of enzyme, indicating its high capability for wastewater treatment. The tyrosinase CLEAs were also exposed to a mixture containing p-cresol, p-chlorophenol and phenol. These were totally removed but required a longer period of contact time due to the presence of a higher load of phenols. It was found that phenol removal was dependent on the dose of immobilised enzyme, the $\mathrm{pH}$ of the phenolic solution and the initial concentration of phenol. The tyrosinase CLEAs were tested for reusability, and it was found that p-cresol was up to $98 \%$ removed after five cycles, while phenol and p-chlorophenol were removed efficiently in the first cycles. A decline in the removal efficiency after three recycles was due to the inhibition of tyrosinase activity by the accumulation of quinonoid as a by-product. The BPA was found to be removed by the sixth cycle [75]. 


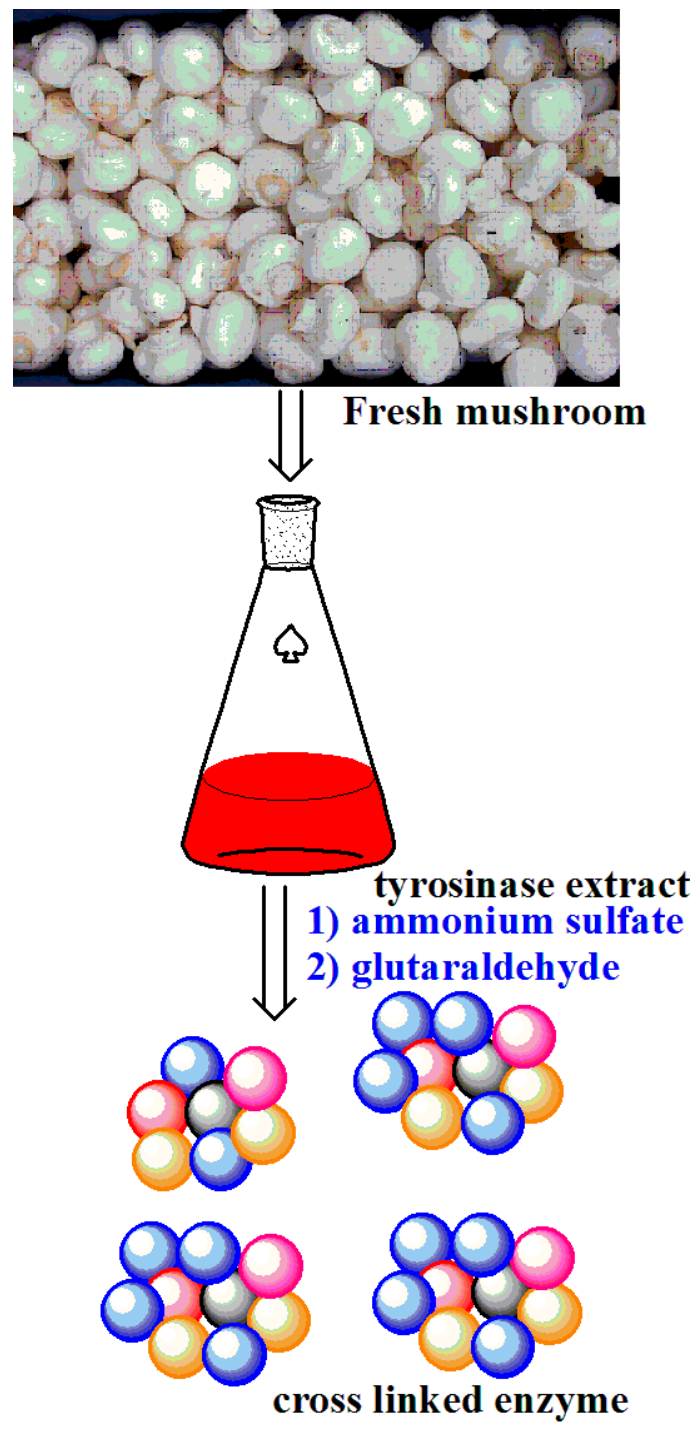

Figure 8. The steps involved in the synthesis of tyrosinase cross-linked enzyme aggregates for elimination of phenolic compounds from water [75].

\subsubsection{Enzyme Nanofibre Supports}

The mechanical properties of nanofibres and their larger surface area allow high enzyme loading. According to Harir et al. (2018), tyrosinase was extracted from Algerian Sahara soil and characterised [56]. This enzyme was then immobilised on nylon nanofibre membranes to enhance its reusability and stability. The nanofibre was used due to quite a lot of factors such as high surface area, ease of modification due to surface functionalisation with enzymes and high porosity and interconnectivity for low hindrance of mass transfer of the enzymes. A high load of $82 \%$ was observed; however, the membranes were only active for up to three cycles because of the formation of melanin as a by-product. Melanin was found to forma precipitate on the membrane and hence caused fouling [56].

The fabrication of a laccase-modified chitosan/poly(vinylalcohol)nanofibre membrane was developed by $\mathrm{Xu}$ et al. (2013) as shown in Figure 9 for the elimination of 2,4-dichlorophenol in water [76]. Glutaraldehyde was used as the cross-linking agent to immobilise the laccase on the membrane. Laccases have three copper atoms in the active site per unit of protein, and these enzymes can oxidise polyphenolic substrates. The removal percentage of 2,4-dichlorophenol by the immobilised laccase reached $87.6 \%$ at $\mathrm{pH} 6$ and at $50{ }^{\circ} \mathrm{C}$. The immobilised laccase exhibited higher stability, reusability, and was reported to be less sensitive to $\mathrm{pH}$ and temperature changes. The reusability 
studies indicated that the removal rate was reduced to $54 \%$ after seven batch adsorption runs, and this was attributed to the loss of enzyme activity. This was caused by the string cross-linking between laccase and the carriers, i.e., PVA, containing large numbers of - $\mathrm{OH}$ groups for bonding. These findings showed that laccase-modified chitosan/poly(vinylalcohol) membrane is an effective candidate for industrial wastewater treatment [76]. In a study by Palvannan et al. (2014), laccase from T. versicolor was immobilised on fabricated zein polyurethane nanofibre membranes via cross-linking using glutaraldehyde [77]. FTIR spectroscopy and field emission scanning electron microscopy (FESEM) showed that the enzyme (laccase) was successfully immobilised on the zein polyurethane nanofibres. The activity of the immobilised laccase on the nanofibres was compared with that of the free enzymes. Immobilised laccase was found to have a relative activity of $85 \%$; it was also demonstrated to have improved thermal and $\mathrm{pH}$ stability in comparison to free laccase. The laccase-modified nanofibres were used to degrade chloroxuron (phenyl urea herbicide). Results indicated the chloroxuron was completely detoxified by the immobilised laccase enzyme. It was demonstrated that the immobilised laccase was able to completely degrade the chloroxuron for up to 25 cycles in the presence of $1 \mathrm{mM}$ HOBt(hydroxybenzotriazole) [77].

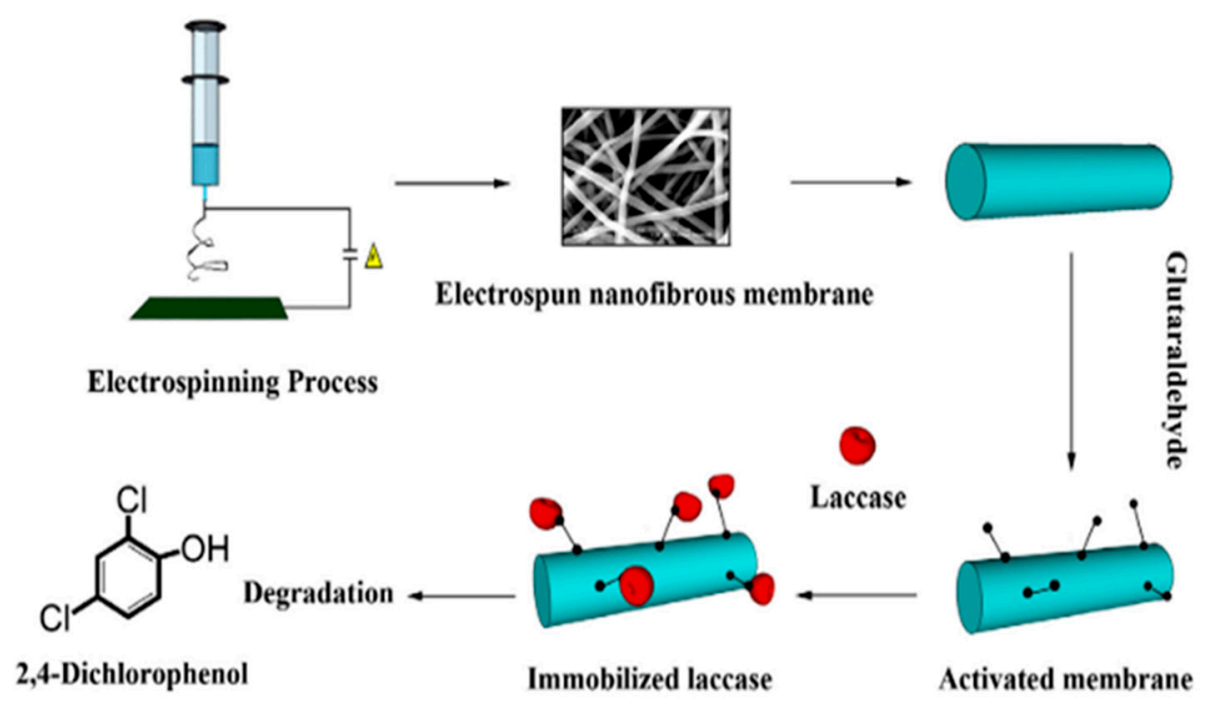

Figure 9. Illustration of laccase enzyme immobilised on chitosan/poly(vinylalcohol)nanofibre membrane [76].

$\mathrm{Xu}$ et al. (2014) conducted a study on the immobilisation of laccase from white-rot fungi on mesoporous vinyl-modified poly(acrylic acid) and silicon dioxide $\left(\mathrm{PAA} / \mathrm{SiO}_{2}\right)$ nanofibres through cross-linking [78]. Glutaraldehyde was used as a cross-linking agent for covalent bond formation between the enzyme and the $\mathrm{PVA} / \mathrm{SiO}_{2}$ nanofibres, and enzyme loading of roughly $417 \mathrm{mg} / \mathrm{g}$ was reported. The physical, chemical and biochemical properties of the laccase-modified $\mathrm{PAA} / \mathrm{SiO}_{2}$ nanofibreswere determined, and its ability to degrade triclosan was investigated. Results revealed that the storage stability was improved, with higher tolerance levels to $\mathrm{pH}$ and temperature changes compared to those of the free laccase. In addition, improved triclosan removal was reported for the laccase-modified $\mathrm{PAA} / \mathrm{SiO}_{2}$ nanofibres; $65 \%$ triclosan removal within $2 \mathrm{~h}$ was reported under the optimum conditions of $\mathrm{pH} 4$ and $30^{\circ} \mathrm{C}$. In comparison, for the free laccase, triclosan removal of $29 \%$ was observed within $2 \mathrm{~h}$ at $\mathrm{pH} 4$ and $30{ }^{\circ} \mathrm{C}$. It was also found that the mesostructure of the nanofibres was favourable for triclosan removal by adsorption and degradation, suggesting its commercial applications, such as for the removal of organic contaminants in water [78]. 


\subsubsection{Laccase Supported on PVDF Membranes by Electron Beam Irradiation}

Membranes use a small amount of enzyme for immobilisation. Electron-beam-induced immobilisation of enzymes on polymer membranes has been studied. In a study by Jahangiri et al. (2018), laccase from Phoma sp. was immobilised on a PVDF membrane via electron beam irradiation [79]. The membrane was first washed in ultrapure water and thereafter immersed in laccase solution for $5 \mathrm{~min}$. Subsequently, it was removed from the solution and irradiated with an electron beam. In this study, electron beam irradiation was used as a form of immobilisation due to the fact that the procedure is an inexpensive, relatively simple and fast one-step immobilisation process. Free and immobilised enzymes were applied in batch experiments for the degradation of pharmaceutically active compounds in municipal wastewater. High mefenamic acid and acetaminophen removal rates of $>85 \%$ were reported for the immobilised enzymes, showing their capability for treating industrial wastewater. These results indicated that the immobilised enzymes were more stable as compared to the free enzymes, especially in typical wastewater temperatures and at $\mathrm{pH}$ ranging between 5 and 9 [79].

\subsubsection{Insolubilisation of Laccases and Tyrosinases}

Laccase Supported on Cross-Linked Chitosan Beads for Decolourisation of Dyes

Ma and co-workers (2018) designed a stable and efficient biocatalyst by entrapping laccase within cross-linked chitosan beads [80]. Specifically, chitosan was first cross-linked with naturally occurring genipin derived from Gardenia jasminoides and Genipa americana. Laccase enzyme obtained from the white-rot fungus Trametes pubescens was then attached to the chitosan-modified beads. The biodegradation capabilities of the laccase-chitosan system were evaluated using synthetic dyes such as Remazol Brilliant Blue R, Reactive Brilliant Blue X-BR, Methylene Blue, Indigo Blue, Acid Black 172, Congo Red, Naphthol Green B, Neutral Red and Crystal Violet. The highest decolourisation was obtained at $77.49 \%$ for Acid Black 172 dye after $96 \mathrm{~h}$. The degradation efficiency of the immobilised enzymes was found to be 1.5-fold higher than that of the free laccase. It was reported that this laccase-chitosan system was able to biodegrade all other types of structurally different dyes without the need of oxidising mediators. Entrapment of the enzyme within genipin-activated chitosan beads was found to enhance the stability and biodegradation capability of the fungal laccase. These findings suggested that the immobilised biocatalyst has a potential for industrial applications, particularly for the treatment of wastewater from dye companies [80].

Laccase and Tyrosinases Supported on Chitosan for Removal of Acetaminophen

Laccase and tyrosinase were combined as cross-linked enzyme aggregates (CLEAs) in a study conducted by Ba et al. (2014) [81]. These enzymes were coupled with chitosan using $\mathrm{N}$-(3-dimethylaminopropyl)-N'-ethylcarbodiimide as a cross-linker. This combined cross-linked enzyme aggregate (combi-CLEA) system was then used for the biodegradation of acetaminophen from wastewater samples, and the by-products were also monitored. Generally, the transformation ratios of the combined CLEA were found to be between $80 \%$ and $100 \%$. It was also found that there were no drastic differences in transformation between the free enzymes and the combi-CLEA; based on the Michaelis-Menten kinetic parameters of the immobilised enzymes, it was confirmed that there was no diffusional restriction of its active sites (Ba et al., 2014). The acetaminophen transformation by the combi-CLEA gave rise to the formation of its oligomers as dimers, 3-hydroxyacetaminophen due to the tyrosinase and trimers and tetramers due to the laccase [81].

\section{Performance of Immobilised/Insolubilised Laccases and Tyrosinases}

\subsection{Operational Stability}

Operational stability determines the reduction of the enzyme's activity from its initial occupation after numerous hydrolysis reactions $[82,83]$. The development of a method for the co-immobilisation of 
laccase with the mediator ABTS (2,2'-azino-bis-(3-ethylbenzothiazoline-6-sulfonic acid) was reported by Yaohua et al. (2019) [84]. Dual-functionalised cellulose (Ce) beads using polymeric glycidyl methacrylate (GMA)and polydopamine (PD) were constructed to encapsulate the ABTS in order to obtain an efficient carrier (PD-GMA-Ce/ABTS).The laccase was then immobilised on the PD-GMA-Ce/ABTS beads via covalent bonding to produce a beaded biocatalyst, PD-GMA-Ce/ABTS-Lac. This biocatalyst was then used to remove indole in wastewater as it is known that indole degradation by free laccase is difficult. With the use of this PD-GMA-Ce/ABTS-Lac biocatalyst, an indole degradation rate of up to 99.7\% was observed. It was reported that the use of PD-GMA-Ce/ABTS-Lac for wastewater treatment applications would eliminate secondary contaminant from the free mediator. The residual activity of the laccase in PD-GMA-Ce/ABTS-Lac after removing indole was measured for operational stability studies. Results revealed that PD-GMA-Ce/ABTS-Lac retained $91.1 \%$ of the enzyme's activity after five cycles and $86.3 \%$ after ten cycles of indole degradation. The high catalytic activity of PD-GMA-Ce/ABTS-Lac beads was influenced by the co-immobilisation effects of both ABTS encapsulation and the covalent bonding of the laccase on the beads. Desorption tests showed very small amounts of laccase elution, which was improved by the strong interactions between the enzyme and the support that was covalently bonded [84].

The immobilisation of laccase on Nylon-6nanofibreswas reported by Fatarella et al. (2014) [85]. The immobilised enzyme retained $29 \%$ of its initial activity whilst the free laccase retained $21 \%$ after seven batches of operation. The loss of enzyme was found to be associated with the inactivation and leakage of the enzyme during applications [85].

In another study, Arica et al. (2017) immobilised laccase on fibrous-polymer-grafted polypropylene chloride film [34]. Poly(glycidyl methacrylate) (PGMA) was grafted onto polypropylene (PP) film to produce the PP-g-PGMA film which was used for the immobilisation of laccase. The residual activity of the laccase in Lac-g-PGMA system for decolourisation of dyes (Brilliant Blue G (BBG), Procion Green H4G (PG-H4G) and Crystal Violet (CV)) was measured by batch system and enzyme reactor over eight cycles. Results revealed a reduction in the activity of the Lac-g-PGMA to $44 \%$, $89 \%$ and 37\% with BBG, PG-H4G and CV, respectively, after five cycles. The decrease in enzyme activity was found to be dependent on the dye structure, which changes the enzymes' shape and makes their function impossible. Decolourisation analysis indicated that the PP-g-PGMA-laccase film system effectively removed the three dyes (BBG, PG-H4G, CV), showing its great potential for numerous biotechnological applications [34].

Laccase was covalently immobilised on citric-acid-functionalised biochar (BC) microparticles (microbars) which were derived from various feedstock(pine wood (BC-PW), pig manure (BC-PM, and almond shell (BC-AS)) in a study by Lonappan et al. (2018) [86]. The laccase-binding capacity of all the biochar microparticles was improved by citric acid pretreatment. These biochar-immobilised laccase microparticles were used for the removal of diclofenac in water. Diclofenac removal of all the three laccase immobilised biochar (BC-PW, BC-PM, BC-AS) was 100\% effective in $220 \mathrm{~min}$. Reusability studies were conducted by measuring the residual activity of the enzyme immobilised on the biochar (BC-PW, BC-PM, BC-AS) samples after five cycles of diclofenac degradation. Operational studies revealed that BC-PW, BC-PM and BC-AS retained $46 \%, 40 \%$ and $43 \%$ of the enzyme's activity, respectively, after five cycles of diclofenac treatment. Results showed that the stability of the enzyme during operation relies on the physicochemical properties of the support, the binding strength with laccase and leaching kinetics [86].

\subsection{Storage Stability}

Storage stability studies are used to study the enzyme's capacity in retaining its structural conformation and activity when subjected to packing, isolation, purification, and physical and chemical manipulations such as heat $[87,88]$. Laccase from the white-rot fungus $T$. versicolor was immobilised on polyamide 6/chitosan (PA6/CHIT) nanofibres and modified by using two spacers, namely bovine serum albumin (BSA) and hexamethylenediamine (HMD), for degradation of bisphenol 
A and $17 \alpha$-ethinylestradiol by Maryškováet al. (2016) [89]. Both the PA6/CHIT-Lac/BSA and PA6/CHIT-Lac/HMD nanofibrous matrices effectively removed bisphenol and $17 \alpha$-ethinylestradiolin water, showing that they could be used as filters for final effluent treatment in facilities that produce high amounts of endocrine disruptors, such as hospitals. The storage stability of the PA6/CHIT-Lac/BSA and PA6/CHIT-Lac/HMD was investigated by incubating the modified nanofibres (PA6/CHIT-Lac (BSA/HMD)) in purified water for 14 days at $4{ }^{\circ} \mathrm{C}$. Results revealed that the PA6/CHIT/Lac-HMD retained $81 \%$ of its initial catalytic activity after 14 days, whilst the PA6/CHIT/Lac-BSA retained only $55 \%$ of its catalytic activity. In contrast, free laccase retained only $51 \%$ of its initial activity after 14 days, which showed that the immobilisation of the laccase improved its storage stability [89].

Storage stability studies were also carried out by Wang et al. (2014) [90]. In this study, the investigators immobilised laccase on electrospun polyacrylonitrile (PAN), polyacrylonitrile/montmorillonite (PAN/MMT) and polyacrylonitrile/montmorillonite/graphene oxide (PAN/MMT/GO) for catechol treatment. Storage stability analysis showed that the laccase immobilised on PAN/MMT/GO had a relatively higher storage stability (64\%) than that immobilised on PAN $(51 \%)$ and on PAN/MMT (52\%). The enzyme immobilised on the nanofibre composite retained $>50 \%$ of its initial activity after 20 days of storage. The PAN/MMT/GO nanofibres have interconnected pores that created abundant sites for immobilisation of laccase, which was adequate for storage stability. The biocatalyst PAN/MMT/GO) removed approximately $39 \%$ of chemical oxygen demand in the catechol solution. Furthermore, it was reported that this method produces no secondary contaminants, making it suitable for future industrial applications [90].

In a study conducted by Misra et al. (2014), laccase was covalently immobilised on poly(ethersulfone) beads that were epoxy-functionalised via irradiation (poly(EPMA-f-PES) for the elimination of Acid Red 1 dye in aqueous solution [91]. The laccase poly(EPMA-f-PES) successfully removed $88 \%$ of Acid Red 1 dye in 15 days. The free and immobilised laccase (poly(EPMA-f-PES) were stored at $4{ }^{\circ} \mathrm{C}$ for 20 days. The catalytic activity of the free laccase was found to be reduced to $54 \%$, whilst the laccase immobilised on the poly(EPMA-f-PES) retained $97 \%$ of its catalytic activity after 20 days. Covalent immobilisation of the enzyme onto poly(EPMA-f-PES) improves its denaturing capabilities, thus producing a high storage stability even after 20 days [91].

Immobilised laccase on spent grain through adsorption and covalent bonding was reported by Machado et al. (2012) [92]. Laccase immobilised on spent grain was incubated in sodium carbonate and phosphate buffer at $4{ }^{\circ} \mathrm{C}$ for 35 days. Storage stability studies revealed that the laccase activity varied from 6000 to $8000 \mathrm{U} / \mathrm{kg}$, showing that the immobilisation of the enzyme on spent grain improved its stability, as the covalent bond between the enzyme and the grain prevented the enzymes from leaching out [92].

\section{3. $p H$ Stability}

The catalytic activity of enzymes is highly dependent on $\mathrm{pH}$; each enzyme has an optimum $\mathrm{pH}$ range, and changes in $\mathrm{pH}$ outside of its range will reduce enzyme activity [93]. For instance, Sathishkumar et al. (2014) investigated the $\mathrm{pH}$ stability and recycle applications for simulated dye (Remazol Black 5, Remazol Brilliant Blue, Reactive Orange 16, Remazol Brilliant Violet, Reactive Red 120) effluent of laccase immobilised on cellulose nanofibres [94]. Free laccase was found to have the highest catalytic activity at an optimum $\mathrm{pH}$ of 5.5 , whereas the optimum $\mathrm{pH}$ for the catalytic activity of the immobilised laccase shifted to 6.5. The shift in $\mathrm{pH}$ was attributed to the adsorption of $\mathrm{H}^{+}$ions from the carboxyl groups available on the surface of the oxidised cellulose electrospun nanofibres. In other words, the charge density on the surface of the oxidised cellulose nanofibre membranes was sufficiently large to change the catalytic microenvironment. Also, the optimum $\mathrm{pH}$ range to retain more than $90 \%$ of the catalytic activity was found to be from $\mathrm{pH} 4$ to 6 for free laccase, while it ranged from $\mathrm{pH} 4$ to 7 for the immobilised laccase, which showed that the immobilisation of the enzyme had an effect on its stability and thus its ability to withstand both acidic and neutral conditions. Decolourisation analysis 
indicated that the laccase immobilised on cellulose nanofibres removed more than $85 \%$ and $70 \%$ of the simulated dye in the fifth and eighth cycles, respectively, showing its ability to treat textile effluent [94].

In another report by El Aty et al. (2017), laccase was immobilised on modified chitosan $\mathrm{Ca}^{2+}$ alginate beads for dye (Congo Red, Crystal Violet) decolourisation [95]. Results indicated that laccase immobilised on chitosan $\mathrm{Ca}^{2+}$ alginate beads effectively removed Congo Red and Crystal Violet dye, and it was thus recommended for industrial scale. The optimum $\mathrm{pH}$ of 4 was reported for the free laccase, and the $\mathrm{pH}$ shifted to 5 for the immobilised enzyme. This was attributed to an increase in the enzyme's active sites through the protonation of $\mathrm{NH}_{2}$ groups from chitosan. The immobilised laccase performed effectively at $\mathrm{pH} 3-6$ with catalytic activity ranging from $66 \%$ to $100 \%$. However, the free laccase lost $66 \%$ of its catalytic activity from $\mathrm{pH} 3-6$ (pH dropped from $120 \%$ to $40 \%$ ), implying that immobilisation of enzymes improves the $\mathrm{pH}$ tolerance [95].

In addition, the immobilisation of laccase on electrospun polyacrylonitrile (PAN) modified organically with montmorillonite (O-MMT) nanofibres to produce a PAN/O-MMT-laccase composite for the removal of Crystal Violet dye in water was reported by Li et al. (2016) [96]. The PAN/O-MMT-laccase composite showed crystal violet degradation of $91 \%$, whereas free laccase only removed $33 \%$ of the dye (Crystal Violet). High efficiency of PAN/O-MMT-laccase composite demonstrated its attractive potential in the elimination of organic contaminates in water. Enzyme activity was investigated between $\mathrm{pH} 2$ and 6. Free laccase was found to have an optimum $\mathrm{pH}$ of 3 , whilst that of the immobilised laccase shifted to $\mathrm{pH}$ 3.5. The slight shift in $\mathrm{pH}$ was because MMT was encapsulated within the PAN polymer matrix, and it was able to absorb hydrogen ions from the buffer solution, making the surface of the PAN/O-MMT support more acidic than the buffer solution itself. It was also noted that $70 \%$ of catalytic activity was retained at $\mathrm{pH} 6$ for the immobilised enzyme, whilst only $22 \%$ of the enzyme was retained at $\mathrm{pH} 6$ for the free laccase, which still shows that the immobilisation of enzymes improves the $\mathrm{pH}$ tolerance of the enzyme [96].

In a report by Olajuyigbe et al. (2019), it was stated that laccase immobilisation on calcium and copper alginate beads by entrapment was dependent on the $\mathrm{pH}$ of the substrate [97]. The free laccase optimum $\mathrm{pH}$ was reported to be $\mathrm{pH}$, and that of the laccase immobilised on calcium and copper alginate beads was $\mathrm{pH} 6$. The decrease in the activity of the immobilised enzyme observed when the $\mathrm{pH}$ shifted from 5 to 6 , particularly for calcium alginate, could be assigned to enzyme inhibition due to the active site of the copper from laccase being bonded to the hydronium ion. It was reported that the free laccase, laccase immobilised on calcium and laccase immobilised on copper alginate retained $64 \%, 48 \%$ and $42 \%$ of their catalytic activity at $\mathrm{pH} 11$, respectively. This finding supported the fact that the $\mathrm{pH}$ stability of the immobilised enzyme relies on the substrate used for immobilisation, indicating that the enzyme activity is dependent on the $\mathrm{pH}$ of the substrate used for immobilisation of the enzyme. The laccase immobilised on calcium and copper alginate beads was then used to degrade bisphenol A in water. Results revealed that laccase immobilised on calcium and laccase immobilised copper alginate beads had removal efficiencies of $71 \%$ and $65.5 \%$, respectively, in 14 days, with both showing their potential for water purification applications [97].

\subsection{Thermal Stability}

Thermal stability is the ability of a substance to resist irreversible changes, whether by its physical structure or chemical structure, often by resisting decomposition or polymerisation at high temperatures [98,99]. The study by Wen et al. (2019) reported on the immobilisation of laccase from T. Versicolor on kaolinite to produce the kaolinite-laccase (Kaolin-Lac) biocatalyst for the treatment of Malachite Green dye combined with $\mathrm{Cd}(\mathrm{II})$ ions in effluent water [100]. The Kaolin-lac biocatalyst decoloured $80 \%$ of Malachite dye after five cycles. In the presence of 3,5- dimethoxy-4-hydroxybenzaldehyde, Kaolin-Lac degraded $100 \%$ of Malachite dye and close to $25 \%$ of $\mathrm{Cd}$ (II) ions in $300 \mathrm{~min}$. This effective biocatalyst was therefore recommended for treating industrial effluent water which contains Malachite dye and Cd(II) ions. Thermal stability studies for both the free and immobilised enzyme were carried out between 30 and $80^{\circ} \mathrm{C}$. Analysis showed 
that the Kaolin-Lac activity increased at a temperature ranging from 30 to $40{ }^{\circ} \mathrm{C}$, showing stability at $40{ }^{\circ} \mathrm{C}(100 \%)$, and it eventually decreased to $18 \%$ at $80^{\circ} \mathrm{C}$. On the other hand, a decrease in free laccase activity was observed, from $99 \%$ at $30{ }^{\circ} \mathrm{C}$ down to $0 \%$ at $80{ }^{\circ} \mathrm{C}$. The immobilisation of enzymes improved the enzymes' tolerance to high temperatures due to reduced conformational flexibility, which normally causes denaturing of the enzyme at high temperatures. Limited substrate diffusion and strong physical bonds between the enzyme and the support also enhanced the high temperature tolerance of the immobilised enzyme [100].

Thermal studies for laccase immobilised on bacterial nanocellulose (BNC) formed by four different strains of bacteria (Komagataei bacterxylinus ATCC-23770, Komagataei bacterxylinus DHU-ZCY-1, Komagataei bacterxylinus DHU-ZGD-1 and Komagataei bacterxylinus DHU-ATCC-1) were conducted by Yuan et al. (2018) [101]. Immobilisation on BNC carriers by adsorption was examined by incubating free and immobilised laccase at $70^{\circ} \mathrm{C}$ for $60 \mathrm{~min}$. Experiments showed that all four types of BNC-immobilised laccase retained a higher enzyme activity compared to the free laccase. There was a slight difference in the amount of laccase activity retained after incubation of all the BNC-immobilised laccase samples. The inactivation of enzymes might have been caused by the breakdown of bonds when the enzyme was exposed to high temperatures. The retained enzyme activity on the BNC-immobilised laccase samples was due to conformational limitations of the enzyme mobility, thus delaying enzyme in activation [101].

Samak et al. (2017) prepared functionalised magnetic graphene oxide (MGO), with the capacity to capture His-tagged $\operatorname{CotA}$ laccase, and then $\mathrm{N} \alpha, \mathrm{N} \alpha$-bis (carboxymethyl)-1-lysine hydrate $\left(\mathrm{NTA}-\mathrm{NH}_{2}\right)(\mathrm{MGO}-\mathrm{NTA})$ was attached to the MGO and separately chelated with $\mathrm{Ni}^{2+}$ and $\mathrm{Cu}^{2+}$ [102]. Decolourisation efficiency on free CotA, MGO-NTA- $\mathrm{Cu}^{2+}$ and MGO-NTA-laccase nanosheets towards Congo Red dye in aqueous solutions were also investigated. Analysis indicated that CotA, MGO-NTA-Cu ${ }^{2+}$, MGO-NTA-laccase nanosheets removed $42.1 \%, 64.2 \%$ and $100 \%$ of Congo Red dye in $5 \mathrm{~h}$, respectively. The MGO-NTA-laccase nanosheets were highly effective and thus recommended for industrial and environment application purposes. His-tagged CotA laccase was then immobilised on the MGO-NTA- $\mathrm{Cu}^{2+}$ and the MGO-NTA-Ni ${ }^{2+}$ nanosheets. For thermal studies, free and immobilised laccase were heated to $80^{\circ} \mathrm{C}$. Results indicated that the immobilised enzyme (MGO-NTA-laccase nanosheet) retained $80 \%$ of its activity, whilst free laccase only retained $28.5 \%$ of its initial activity after $3 \mathrm{~h}$. This was due to the porous morphology of the MGO-NTA. The rigid structure of the laccase was improved due to the interaction of the enzyme with the MGO-NTA, thus making laccase more resistant to heat inactivation [102].

According to Shi et al. (2014), laccase was immobilised on concanavalin-A-activated $\mathrm{Fe}_{3} \mathrm{O}_{4}$ nanoparticles (GAMNs-Con-A) [83]. Thermal stability studies were carried out by incubating free laccase and the laccase immobilised on the GAMNs-Con-A (GAMNs-Con-A-L) at $100{ }^{\circ} \mathrm{C}$ for $2 \mathrm{~h}$. Free laccase lost its catalytic activity within $2 \mathrm{~h}$ of treatment at $60^{\circ} \mathrm{C}$, whilst the GAMNs-Con-A-L retained $40 \%$ of its initial activity under the same experimental conditions. Results showed that the immobilisation of laccase on GAMNs-Con-A improved its stability due to its interactions with the support enhancing the rigidity of the laccase molecule to withstand heat inactivation [83].

\subsection{Effect of Inhibitors on Enzyme Activity}

An inhibitor is a compound that alters the catalytic action of an enzyme and thus slows down or stops catalysis. Inhibition studies are conducted to obtain information on the reaction mechanism of the enzyme [103]. Recently, Saoudi and Ghaouar (2019) conducted a study on biocatalytic characterisation of free and immobilised laccase in their activation zones [103]. Sodium azide and ethylenediaminetetraacetic (EDTA), citric, sulphamic and oxalic acids were used to investigate inhibition of the laccase enzyme. Results revealed that the laccase activity was greatly influenced by sodium azide $(0.005 \mathrm{mM})$ because of its potential to attach to the trinuclear centre, producing two different adducts. Laccase activity was entirely inhibited by oxalic acid and sulphamic acid at a concentration of $40 \mathrm{mM}$; however, citric acid and EDTA inhibited enzyme activity at even lower concentrations than the 
inhibitor concentration reported for oxalic acid and sulphamic acid. The inhibition of the enzyme at different concentrations was dependent on the nature of inhibitor interaction with the enzyme to form copper ion complexes [103].

In a study by Chen et al. (2018), a microplate assay integrating tyrosinase-immobilised magnetic nanoparticles (TYR-MNPs) was developed for tyrosinase inhibitor screening [104]. Extracts of natural products were incubated with the TYR-MNPs and the formation of L-3,4-dihydroxyphenylalanine (L-DOPA) was catalysed by the TYR-MNPs. Ascorbic (vitamin C), kojic and tranexamic acids were used to investigate the inhibition of tyrosinase activity. Results revealed that the inhibitory effect was greater on the free tyrosinase than on the immobilised tyrosinase (TYR-MNPs).Inhibition of the free tyrosinase was associated with less L-DOPA being produced due to the antioxidant activity of vitamin C, but no inhibitory effect on the TYR-MNPs was observed due to the fact that vitamin $C$ was washed away before TYR-MNPs were incorporated. Also, it was reported that kojic and tranexamic acids had a significant inhibitory effect on both the free and immobilised tyrosinase enzyme, which was attributed to the kojic acid being a copper chelator and tranexamic acid being a tyrosinase inhibitor, as it binds to the active sites of the enzyme [104].

In a similar study conducted by Stapelberg et al. (2018), South African medicinal plants that have tyrosinase enzyme inhibition properties and their influence on gene expression was evaluated [105]. Plant extracts of Ormocarpum trichocarpum, Kalanchoe thyrsiflora, Myrsine pillansii, Vachellia karroo, Rapanea melanophloeos and Myrsine africana were evaluated for their tyrosinase inhibition capacity. The most effective inhibition of the tyrosinase enzyme was reported for Ormocarpum trichocarpum and Vachellia karroo; these medicinal extracts inhibited $50 \%$ of the tyrosinase enzyme at concentrations of 2.95 and $6.84 \mu \mathrm{g} / \mathrm{L}$, respectively [105].

According to Jaiswal et al. (2016), papaya laccase was immobilised on chitosan beads to improve stability of the enzyme and for dye (Indigo Carmine) decolourisation in water [106]. The papaya laccase immobilised on chitosan beads completely $(100 \%)$ decoloured Indigo Carmine dye, while the free laccase which only removed $56 \%$ of the dye. Based on these findings it was recommended that papaya laccase immobilised on chitosan be exploited for water purification application. The tolerance of the immobilised laccase to a number of metal ions (sodium, magnesium, calcium, manganese, copper, cobalt, iron, cadmium and mercury) and to organic solvents (ethylenediaminetetraacetic acid (EDTA) and sodium dodecyl sulphate (SDS)) was investigated [106]. Results indicated that the laccase immobilised enzyme activated with manganese $\left(\mathrm{Mn}^{2+}\right)$ had the highest activation, $\sim 5$-fold at $1 \mathrm{mM}$; that of cobalt $\left(\mathrm{Co}^{2+}\right)$ was $\sim 3$-foldat $1 \mathrm{mM}$ whilst the activation for the other metals was $\sim 2$-fold. Activation of laccase by metal ions was attributed to the structure of laccase, which contains four copper atoms situated at three copper types (I, II and III) which conducts monoelectronic oxidation of suitable substrate. In addition, $1 \mathrm{mM}$ of both EDTA and SDS retained $80 \%$ laccase activity, while the free enzyme retained only $70 \%$ of the activity. The increase in inhibition resistance for immobilised enzymes is due to the minimised mobility of the protein chain after immobilisation. The substrate and strategy of immobilisation also has an effect on inhibition. Some chemical compounds in the substrate or during the immobilisation technique can bond with enzyme's active site, reducing its catalytic activity. It was also reported that no inhibition was observed for free laccase [106].

\subsection{Kinetic Behaviour}

Analysis of enzyme kinetic data helps in understanding the effects of complexation of an enzyme's interaction with a substrate after dissociation as well as the efficiency of the catalyst $[107,108]$. For instance, Touahar et al. (2014) developed a combined cross-linked enzyme aggregate (combi-CLEA) by cross-linking three oxidative enzymes, namely laccase (Lac), glucose oxidase (GOD) and versatile peroxidase (VP) enzymes after aggregation and evaluated this combi-CLEA for the elimination of pharmaceuticals (acetaminophen, mefenamic acid, naproxen, diclofenac and indomethacin) [105]. The combined CLEA was able to remove acetaminophen, naproxen, mefenamic acid, diclofenac and indomethacin in water due to the presence of VP and laccase, showing that the biocatalyst can be 
used for industrial application for water treatment. Kinetic parameters for laccase activities were determined at around $20^{\circ} \mathrm{C}$, and 2,2'-azino-bis-(3-ethylbenzothiazoline-6-sulfonic acid) was used as a substrate, with its concentration being varied from 0.05 to $2 \mathrm{mM}$, dissolved in $0.1 \mathrm{M}$ citric acid/0.1 M citric acid/0.1 $\mathrm{M}$ disodium hydrogen phosphate buffer at a $\mathrm{pH}$ of 3 . Kinetic studies were carried out and showed that the Michaelis-Menten constant $\left(K_{\mathrm{m}}\right)$ of the free laccase was $216 \mu \mathrm{M}$, while a $K_{\mathrm{m}}$ of $287 \mu \mathrm{M}$ was reported for the combi-CLEA. The low $K_{\mathrm{m}}$ values indicated that the insoluble laccase had a slightly higher affinity towards 2,2' -azino-bis-(3-ethylbenzothiazoline-6-sulfonic acid) because chitosan was suspected to have increased the affinity for the substrate, as it creates hyperactivation of laccase. Although the free laccase had a higher turnover number of $8.68 \mu \mathrm{mol} \cdot \mathrm{s}^{-1} \cdot \mathrm{mg}^{-1}$, compared to $3.38 \mu \mathrm{mol} \cdot \mathrm{s}^{-1} \cdot \mathrm{mg}^{-}$recorded for combi-CLEA, almost the same biocatalytic efficiency was reported for free laccase and combi-CLEA $\left(0.02\right.$ and $\left.0.03 \mathrm{Ls}^{-1} \mathrm{mg}^{-1}\right)$ [109].

In another study, Hassani et al. (2013) cross-linked laccase and entrapped the cross-linked enzyme aggregates (CLEAs) in a polymer network comprised of chitosan and 3-aminopropyltriethoxysilane (EPES-lac) [110]. Kinetic parameters of the free enzyme, CLEA and EPES-lac were determined at $20^{\circ} \mathrm{C}$ and at $\mathrm{pH}$ 3. Kinetic studies using the Michaelis-Menten model indicated that the EPES-lac $\left(K_{\mathrm{m}}=0.213\right.$ $\pm 0.026 \mathrm{mM}$ )had a double affinity for 2,2'-azino-bis-(3-ethylbenzothiazoline-6-sulfonic acid) than that of the unmodified CLEA free laccase $\left(K_{\mathrm{m}}=0.128 \pm 0.018 \mathrm{mM}\right)$. The high affinity of EPES-lac towards 2,2'-azino-bis-(3-ethylbenzothiazoline-6-sulfonic acid) is associated with the hyperactivation of laccase when it is in contact with chitosan [110].

Yildiz et al. (2012) reported L-DOPA synthesis catalysed by tyrosinase immobilised on poly(ethylene oxide) [111]. For the synthesis of L-DOPA, two types of biosensors were developed by immobilising tyrosinase on the conducting polymers, namely 3-methylthienyl methacrylate-co-p-vinylbenzyloxy poly(ethylene oxide)/polypyrrole (CP-co-PPy) and thiophene-capped poly(ethyleneoxide)/polypyrrole (PEO-co-PPy).These biosensors were synthesised electrochemically and the tyrosinase was immobilised by entrapment through electropolymerisation. For L-DOPA synthesis, L-tyrosine $(0.5-2.5 \mathrm{mM})$ was used as the substrate, dissolved in a solution of $0.01 \mathrm{M}$ tyrosinase, $1 \mathrm{~mL}$ of $\mathrm{HCl}(2 \mathrm{M})$ and $1 \mathrm{~mL}$ of $\mathrm{NaOH}(2 \mathrm{M})$. The kinetic parameters (Michaelis-Menten constant $\left(K_{\mathrm{m}}\right)$ and maximum reaction rate of the enzyme $\left(V_{\max }\right)$ ) were determined for the synthesised biosensors. The $K_{\mathrm{m}}$ values for the free tyrosinase and for the CP-co-PPy and PEO-co-PPy biosensors were found to be $6.4,9.2$ and $3.4 \mathrm{mM}$, respectively. The reduction in $K_{\mathrm{m}}$ values for the PEO-Co-PPy biosensor was attributed to the higher affinity of the entrapped enzyme for the substrate than the free enzyme, whilst $K_{\mathrm{m}}$ values for the CP-co-PPy biosensor were high, which showed that the electrode had a low affinity towards L-tyrosinase owing to the structural changes of the enzyme as a consequence of entrapment in the lattice [111].

Kinetic studies were carried out on the covalent immobilisation of laccase on graphene oxide (GO) nanosheets, as described by Kashefi et al. (2019); the prepared nano-biocatalyst was then evaluated for the biodegradation of Azo dyes in coloured wastewater [112]. The reaction kinetics of the enzyme were observed using ABTS(2,2'-azino-bis-(3-ethylbenzothiazoline-6-sulfonic acid) as a substrate $(1.8 \mathrm{~mL})$ in a solution of $100 \mathrm{mM}$ sodium acetate buffer with a $\mathrm{pH}$ of 5 at room temperature and $200 \mu \mathrm{L}$ of the enzyme solution. The Michaelis-Menten constant $\left(K_{\mathrm{m}}\right)$ of the free laccase was found to be $0.71 \pm 0.06 \mathrm{mM}$, whereas a $K_{\mathrm{m}}$ value of $1.16 \pm 0.07 \mathrm{mM}$ was reported for the immobilised laccase. This 1.63-fold increase in the $K_{\mathrm{m}}$ value of the immobilised enzyme compared to that of the free enzyme indicates restricted access to the reactive sites of the enzyme, high mass transfer resistance and enzyme conformational changes. Decolourisation analysis showed that the immobilised enzyme removed more than $75 \%$ of DR23 and DR92 azo dyes after six cycles, implying that the nano-biocatalyst can be used in extending green technologies for wastewater treatment [112].

\section{Conclusions}

Laccase and tyrosinase can be immobilised by adsorption/noncovalent bonding, covalent bonding, cross-linking and entrapment/encapsulation. All enzyme immobilisation methods utilise 
a support/matrix, except in the cross-linking method, which requires a cross-linker to form enzyme aggregates. Enzymes are supported on numerous inorganic and organic materials such as nanofibre membranes and carbon nanotubes. In comparison with the free enzymes, the immobilisation of laccase/tyrosinase improves storage stability and catalytic activity and enables the production of efficient and stable biocatalysts with the ability to degrade phenolic compounds in water. Enzyme immobilisation techniques such as electrostatic adsorption and covalent bonding to the support matrix produce immobilised enzymes that have highly enhanced activity and stability and are less prone to leaching due to strong bonds and electrostatic forces of attraction between the support and the enzyme. For laccase and tyrosinase enzymes, the optimal pH is acidic, as they show increased activity; however, immobilisation of enzymes slightly increases $\mathrm{pH}$ levels, thus reducing enzyme activity. Immobilisation of the enzymes enhances the thermal stability, which increases the lifespan of the enzyme and allows reuse (reactivation).It was shown that immobilised enzymes are affected by enzyme inhibitors which alter the catalytic action of the enzymes and thus slow down or stop the catalysis. Therefore, there is a need for more studies to be conducted to overcome the effects of the inhibitors on immobilised enzymes. The kinetic behaviour of free and immobilised enzymes is dependent to the support/matrix, cross-linkers, substrate used and the solution at hand. The review of the literature indicated that that more studies have been conducted on the immobilisation of laccase than on tyrosinase immobilisation. Laccase enzymes can oxidise several aromatic compounds, such as substituted mono- and polyphenols, thiol compounds and aromatic amines, with subsequent production of radicals, whereas tyrosinases oxidise $o$-diphenols and $p$-monophenols to quinones.

Author Contributions: S.B. and S.P.M. conceptualised the idea, T.N. wrote the paper, S.P.M. and S.B. reviewed and edited the drafts, S.P.M. and S.B. were involved in financial acquisition. All authors have read and agreed to the published version of the manuscript.

Funding: This work was supported in part by resources of the Institut Polytechnique Rural de Formation et de Recherche Appliquée of Katibougou, Mali; Thuthuka National Research Foundation (TTK-NRF) (Grant No. TTK 180427324698); Water Research Commission (Project No. K5/2488/3); DST/Mintek Nanotechnology Innovation Centre (NIC); Centre for Nanomaterials (University of Johannesburg); Eskom Tertiary Education Support Programme (TESP) (05.15.286378.15); and the Faculty of Science (University of Johannesburg).

Conflicts of Interest: The authors declare no conflict of interest.

\section{References}

1. Hongyan, L.; Zexiong, Z.; Shiwei, X.; He, X.; Yinian, Z. Study on transformation and degradation of bisphenol A by Trametes versicolor laccase and simulation of molecular docking. Chemosphere 2019, 224, 743-750. [CrossRef] [PubMed]

2. Kotik, M.; Markov, E. Biodegradation of phenolic compounds by Basidiomycota and its phenol oxidases: A review. Chemosphere 2016, 149, 373-382.

3. Dinçer, A.; Becerik, S.; Aydemir, T. Immobilization of tyrosinase on chitosan-clay composite beads. Int. J. Biol. Macromol. 2012, 50, 815-820. [CrossRef] [PubMed]

4. Giroud, F.; Minteer, S.D. Anthracene-modified pyrenes immobilized on carbon nanotubes for direct electroreduction of $\mathrm{O} 2$ by laccase. Electrochem. Commun. 2013, 34, 157-160. [CrossRef]

5. Xu, H.; Sun, X.; Wang, S.; Song, C.; Wang, S. Development of laccase/graphene oxide membrane for enhanced synthetic dyes separation and degradation. Sep. Purif. Technol. 2018, 204, 255-260. [CrossRef]

6. Beck, S.; Berry, E.; Duke, S.; Miliken, A.; Patterson, H.; Prewett, D.L.; Rae, T.C.; Sridgar, V.; Wendland, N.; Gregory, B.W.; et al. Characterization of Trametes versicolor laccase-catalyzed degradation of estrogenic pollutants: Substrate limitation and product identification. Int. Biodeterior. Biodegrad. 2018, 127, $146-159$. [CrossRef]

7. Bilal, M.; Adeel, M.; Rasheed, T.; Zhao, Y.; Iqbal, M.N. Emerging contaminants of high concern and their enzyme-assisted biodegradation-A review. Environ. Int. 2019, 124, 336-353. [CrossRef]

8. Pang, R.; Li, M.; Zhang, C. Degradation of phenolic compounds by laccase immobilized on carbon nanomaterials: Diffusional limitation investigation. Talanta 2015, 131, 38-45. [CrossRef] 
9. Sun, K.; Li, S.; Yu, J.; Gong, R.; Si, Y.; Liu, X.; Chu, G. Cu2+ p -assisted laccase from Trametes versicolor enhanced self-polyreaction of triclosan. Chemosphere 2019, 225, 745-754. [CrossRef]

10. Songulashvili, G.; Jimenéz-Tobón, G.A.J.; Jaspers, C.; Penninckx, M.J. Immobilized laccase of Cerrena unicolor for elimination of endocrine disruptor micropollutants. Fungal Biol. 2012, 6, 883-889. [CrossRef]

11. Li, F.; Yu, Y.; Wang, Q.; Yuan, J.; Wang, P.; Fan, X. Polymerization of dopamine catalyzed by laccase: Comparison of enzymatic and conventional methods. Enzym. Microb. Technol. 2018, 119, 58-64. [CrossRef]

12. Bilal, M.; Rasheed, T.; Nabeel, F.; Iqbal, M.N.; Zhao, Y. Hazardous contaminants in the environment and their laccase-assisted degradation-A review. J. Environ. Manag. 2019, 234, 253-264. [CrossRef] [PubMed]

13. Fortes, C.C.S.; Daniel-da-Silva, A.D.; Xavier, A.M.R.B.; Tavares, A.P.M. Opmtimization of enzyme immobilization on functionalized magnetic nanoparticles for laccase biocatalytic reactions. Chem. Eng. Process. 2017, 117, 1-8. [CrossRef]

14. Ghosh, B.; Saha, R.; Bhattacharya, D.; Mukhopadhyay, M. Laccase and its source of sustainability in an enzymatic biofuel cell. Bioresour. Technol. Rep. 2019, 6, 268-278. [CrossRef]

15. Ba, S.; Kumar, V.V. Recent developments in the use of tyrosinase and laccase in environmental applications. Crit. Rev. Biotechnol. 2017, 37, 819-832. [CrossRef]

16. Brugnari, T.; Pereira, M.G.; Bubna, G.A.; de Freitas, E.N.; Contato, A.G.; Correa, R.C.G.; Castoldi, R.; de Souza, C.G.M.; Polizeli, M.T.; Bracht, A.; et al. A highly reusable MANAE-agarose-immobilized Pleurotusostreatus laccase for degradation of bisphenol A. Sci. Total Environ. 2018, 634, 1346-1351. [CrossRef]

17. Lassouane, F.; Aït-Amar, H.; Amrani, S.; Rodriguez-Couto, S. A promising laccase immobilization approach for Bisphenol A removal from aqueous solutions. Bioresour. Technol. 2019, 271, 360-367. [CrossRef]

18. Wen, X.; Zeng, Z.; Du, C.; Huang, D. Immobilized laccase on bentonite-derived mesoporous materials for removal of tetracycline. Chemosphere 2019, 222, 865-871. [CrossRef]

19. Costa, J.B.; Lima, M.J.; Sampaio, M.J.; Neves, M.C.; Faria, J.L.; Torres, S.M.; Tavares, A.P.M.; Silva, C.G. Enhanced biocatalytic sustainability of laccase by immobilization on functionalized carbon nanotubes/polysulfone membranes. Chem. Eng. J. 2019, 355, 974-985. [CrossRef]

20. Fathali, Z.; Rezaei, S.; Ali, M.; Habibi-Rezaei, M. Catalytic phenol removal using entrapped cross-linked laccase aggregates. Int. J. Biol. Macromol. 2019, 122, 359-366. [CrossRef]

21. Bayramoglu, G.; Akbulut, A.; Arica, M.Y. Immobilization of tyrosinase on modified diatom biosilica: Enzymatic removal of phenolic compounds from aqueous solution. J. Hazard. Mater. 2013, 244, 528-536. [CrossRef] [PubMed]

22. Guan, Y.; Liu, L.; Chen, C.; Kang, X.; Xie, Q. Effective immobilization of tyrosinase via enzyme catalytic polymerization of L-DOPA for highly sensitive phenol and atrazine sensing. Talanta 2016, 160, 125-132. [CrossRef] [PubMed]

23. Kampmann, M.; Boll, S.; Kossuch, J.; Bielechi, J.; Uhl, S.; Kleiner, B.; Wichmann, R. Efficient immobilization of mushroom tyrosinase utilizing whole cells from Agaricusbisporus and its application for degradation of bisphenol A. Water Res. 2014, 57, 295-303. [CrossRef]

24. Carmango, J.R.; Bacarrin, M.; Pereira, P.A.; Campos, A.M.; Oliveira, G.G.; Fhilo, O.F.; Oliveira, O.N.; Janegitz, B.C. Electrochemical biosensor made with tyrosinase immobilized in a matrix of nanodiamonds and potato starch for detecting phenolic compounds. Anal. Chim. Acta 2018, 1034, 137-143.

25. Lasmi, K.; Derder, H.; Kernad, A.; Sam, S.; Abib, H.; Belhousse, S.; Tighilt, F.Z.; Hamdani, K.; Gabouze, N. Tyrosinase immobilization on functionalized porous silicon surface for optical monitoring of pyrocatechol. Appl. Surf. Sci. 2018, 446, 3-9. [CrossRef]

26. Antecka, K.; Zdarta, J.; Siwińska-Stefańska, K.; Sztuk, G.; Jankowsaka, E.; Oleskowicz-Popiel, P.; Jesionowski, T. Synergistic degradation of dye wastewaters using binary or ternary oxide systems with immobilized laccase. Catalysts 2018, 8, 402. [CrossRef]

27. Bilal, M.; Asgher, M.; Iqbal, H.M.N.; Hu, H. Bio-based degradation of emerging endocrine-disrupting and dye-based pollutants using cross-linked enzyme aggregates. Environ. Sci. Pollut. Res. 2017, 24, 7035-7041. [CrossRef]

28. Carlsson, N.; Gustafsson, H.; Thörn, C.; Olsson, L.; Holmberg, K.; Åkerman, B. Enzymes immobilized in mesoporous silica: A physical-Chemical perspective. Adv. Colloid Interface Sci. 2014, 205, 339-360. [CrossRef] 
29. Jun, L.Y.; Yon, L.S.; Mubarak, N.M.; Bing, C.H.; Pan, S.; Danquah, M.K.; Abudullah, E.C.; Khalid, M. An overview of immobilized enzyme technologies for dye and phenolic removal from wastewater. J. Environ. Chem. Eng. 2019, 7, 102961-102975. [CrossRef]

30. An, N.; Hui, C.; Yu, X.; Shen, D.; Hua, W. Immobilization of enzymes on clay minerals for biocatalysts and biosensors. Appl. Clay Sci. 2015, 114, 283-296. [CrossRef]

31. Amaly, N.; Si, Y.; Chen, Y.; Moghazzy, A.Y.; Zhao, C.; Zhang, R.; Sun, G. Reusable anionic sulfonate functionalized nanofibrous membranes for cellulase enzyme adsorption and separation. Colloids Surf. B Biointerfaces 2018, 170, 588-595. [CrossRef] [PubMed]

32. Polyák, P.; Urbán, E.; Nagy, G.N.; Vértessy, B.G.; Pukánszky, B. The role of enzyme adsorption in the enzymatic degradation of an aliphatic polyester. Enzym. Microb. Technol. 2019, 120, 110-116. [CrossRef] [PubMed]

33. Ahmed, S.A.; Wahab, W.A.A.; Abdel-Hameed, S.M. Comparative study in kinetics and thermodynamic characteristics of immobilized caseinase on novel support from basalt by physical adsorption and covalent binding. Biocatal. Agric. Biotechnol. 2019, 18, 101028-101039. [CrossRef]

34. Arica, M.Y.; Salih, B.; Celikbicak, O.; Bayramoglu, G. Immobilization of laccase on the fibrous polymer-grafted film and study of textile dye degradation by MALDI-ToF-MS. Chem. Eng. Res. Des. 2017, 128, 107-119. [CrossRef]

35. Lonappan, L.; Liu, Y.; Rouissi, T.; Kaur, S.; Verma, M.; Surampalli, R.Y. Adsorptive immobilization of agro-industrially produced crude laccase on various micro-biochars and degradation of diclofenac. Sci. Total Environ. 2018, 640, 1251-1258. [CrossRef]

36. Hyun, J.; Hong, S.; Jin, H.; Ha, S.; Kim, J. Precipitated and chemically-crosslinked laccase over polyaniline nanofiber for high performance phenol sensing. Chemosphere 2016, 143, 142-147.

37. Li, D.; Luo, L.; Pang, Z.; Ding, L.; Wang, Q.; Ke, H.; Huang, F.; Wei, Q. Novel phenolic biosensor based on a magnetic polydopamine-laccase-nickel nanoparticle loaded carbon nanofiber composite. Appl. Mater. Interfaces 2014, 6, 5144-5151. [CrossRef]

38. Allertz, P.J.; Berger, S.; Sellenk, G.; Dittmer, C.; Dietze, M.; Stahmann, K.P.; Salchert, K. Approaching immobilization of enzymes onto open porous Basotect. Catalysts 2017, 7, 359. [CrossRef]

39. Özen, F.; Günel, A.; Baran, A. DNA-binding, enzyme inhibition, and photochemical properties of chalcone-containing metallophthalocyanine compounds. Bioorg. Chem. 2018, 81, 71-78. [CrossRef]

40. Holmberg, K. Interactions between surfactants and hydrolytic enzymes. Colloids Surf. B Biointerfaces 2018, 168, 169-177. [CrossRef]

41. Ichi-Ribault, S.E.; Zebda, A.; Tingry, S.; Petit, M.; Suherman, A.L.; Boualam, A.; Cinquin, P.; Martin, D.K. Performance and stability of chitosan-MWCNTs-laccase biocathode: Effect of MWCNTs surface charges and ionic strength. J. Electroanal. Chem. 2017, 799, 26-33. [CrossRef]

42. Gascon, V.; Blanco, R.M. Efficient retention of laccase by non-covalent immobilization on amino-functionalized ordered mesoporous silica. Appl. Catal. A Gen. 2014, 482, 116-126. [CrossRef]

43. Xia, T.; Liu, C.; Hu, J.; Guo, C. Improved performance of immobilized laccase on amine-functioned magnetic $\mathrm{Fe}_{3} \mathrm{O}_{2}$ nanoparticles modified with polyethylenimine. Chem. Eng. J. 2016, 295, 201-206. [CrossRef]

44. Abreu Silveira, E.; Perez, S.M.; Basso, A.; Serban, S.; Mamede, R.P.; Tardioli, P.W.; Farinas, C.S.; Casterjon, N.; Lorenete, G.; Martin, J.; et al. Biocatalyst engineering of Thermomyces lanuginosus lipase adsorbed on hydrophobic supports: Modulation of enzyme properties for ethanolysis of oil in solvent-free systems. J. Biotechnol. 2019, 289, 126-134. [CrossRef]

45. Nalder, T.D.; Kurtovic, I.; Barrow, C.J.; Marshall, S.N. A simplified method for active-site titration of lipases immobilised on hydrophobic supports. Enzym. Microb. Technol. 2018, 113, 18-23. [CrossRef]

46. Urena, Y.R.C.; Lisboa-filho, P.N.; Szardenings, M.; Gatjen, L.; Noeske, P.M.; Rischka, K. Formation and composition of adsorbates on hydrophobic carbon surfaces from aqueous laccase-maltodextrin mixture suspension. Appl. Surf. Sci. 2016, 385, 216-224. [CrossRef]

47. Tavares, A.P.M.; Silva, C.G.; Draz, G.; Faria, J.L. Laccase immobilization over multi-walled carbon nanotubes: Kinetic, thermodynamic and stability studies. J. Colloid Interface Sci. 2015, 454, 52-60. [CrossRef]

48. Han, Z.; Zhao, L.; Yu, P.; Chen, J.; Wu, F.; Mao, L. Comparative investigation of small laccase immobilized on carbon nanomaterials for direct bioelectrocatalysis of oxygen reduction. Electrochem. Commun. 2019, 101, 82-87. [CrossRef] 
49. Cosnier, S.; Holzinger, M.; Goff, A.L. Recent advances in carbon nanotube-based enzymatic fuel cells. Front. Bioeng. Biotechnol. 2014, 2, 1-6. [CrossRef]

50. Cieh, N.L.; Sulaiman, S.; Mokhtar, M.N.; Naim, M.N. Bleached kenaf microfiber as a support matrix for cyclodextrin glucanotransferase immobilization via covalent binding by different coupling agents. Process Biochem. 2017, 56, 81-89. [CrossRef]

51. Sun, H.; Yang, H.; Huang, W.; Zhang, S. Immobilization of laccase in a sponge-like hydrogel for enhanced durability in enzymatic degradation of dye pollutants. J. Colloid Interface Sci. 2015, 450, 353-360. [CrossRef] [PubMed]

52. Asgher, M.; Noreen, S.; Bilal, M. Enhancing catalytic functionality of Trametes versicolor IBL-04 laccase by immobilization on chitosan microspheres. Chem. Eng. Res. Des. 2017, 119,1-11. [CrossRef]

53. Shari, M.; Robatjazi, S.; Sadri, M.; Mosaabadi, J.M. Immobilization of organophosphorus hydrolase enzyme by covalent attachment on modified cellulose micro fibers using different chemical activation strategies: Characterization and stability studies. Chin. J. Chem. Eng. 2019, 27, 191-199. [CrossRef]

54. Abdollahi, K.; Yazdani, F.; Panahi, R. Covalent immobilization of tyrosinase onto cyanuric chloride crosslinked amine-functionalized superparamagnetic nanoparticles: Synthesis and characterization of the recyclable nanobiocatalyst. Int. J. Biol. Macromol. 2017, 94, 396-405. [CrossRef]

55. Koloti, L.E.; Gule, N.P.; Arotiba, O.A.; Malinga, S.P. Laccase-immobilized dendritic nanofibrous membranes as a novel approach towards the removal of bisphenol A. Environ. Technol. 2018, 39, 392-404. [CrossRef]

56. Harir, M.; Bellahcene, M.; Baratto, M.C.; Pollini, S.; Rossolini, G.M.; Trabalzini, L.; Fatarella, E.; Pogni, R. Isolation and characterization of a novel tyrosinase produced by Sahara soil actinobacteria and immobilization on nylon nanofiber membranes. J. Biotechnol. 2018, 265, 54-64. [CrossRef]

57. Xu, R.; Chi, C.; Li, F.; Zhang, B. Laccase-Polyacrylonitrile nanofibrous membrane: Highly immobilized, stable, reusable, and efficacious for 2,4,6-trichlorophenol removal. Appl. Mater. Interfaces 2013, 5, 12554-12560. [CrossRef]

58. Soumano, L.; Bellenger, J.; Jones, J.P.; Cabana, H. A hybrid bioreactor based on insolubilized tyrosinase and laccase catalysis and micro filtration membrane remove pharmaceuticals from wastewater. Chemosphere 2018, 201, 749-755.

59. Tirunagari, H.; Basetty, S.; Rode, H.B.; Fadnavis, N.W. Crosslinked enzyme aggregates (CLEA) of phytase with soymilk proteins. J. Biotechnol. 2018, 282, 67-69. [CrossRef]

60. Jabbari, S.; Dabirmanesh, B.; Khajeh, K. Specificity enhancement towards phenolic substrate by immobilization of laccase on surface plasmon resonance sensor chip. J. Mol. Catal. B Enzym. 2015, 121, 32-36. [CrossRef]

61. Kumar, V.V.; Sivanesan, S.; Cabana, H. Magnetic cross-linked laccase aggregates-Bioremediation tool for decolorization of distinct classes of recalcitrant dyes. Sci. Total Environ. 2014, 487, 830-839. [CrossRef] [PubMed]

62. Yang, J.; Xu, X.; Yang, X.; Ye, X.; Lin, J. Cross-linked enzyme aggregates of Cerrena laccase: Preparation, enhanced $\mathrm{NaCl}$ tolerance and decolorization of Remazol Brilliant Blue Reactive. J. Taiwan Inst. Chem. Eng. 2016, 65, 1-7. [CrossRef]

63. Pavinatto, A.; Mercante, L.A.; Facure, M.H.M.; Pena, R.B. Ultrasensitive biosensor based on polyvinylpyrrolidone/chitosan/reduced graphene oxide electrospun nanofibers for $17 \alpha$-Ethinylestradiol electrochemical detection. Appl. Surf. Sci. 2018, 458, 431-437. [CrossRef]

64. Pinto, S.C.; Rodrigues, A.R.; Saraiva, J.M.A.; Lopes-da-Silva, J.A. Catalytic activity of trypsin entrapped in electrospunpoly( $\epsilon$-caprolactone) nanofibers. Enzym. Microb. Technol. 2015, 79, 8-18. [CrossRef]

65. Chimphango, A.F.A.; van Zyl, W.H.; Görgens, J.F. In situ enzymatic aided formation of xylan hydrogels and encapsulation of horse radish peroxidase for slow release. Carbohydr. Polym. 2012, 88, 1109-1117. [CrossRef]

66. Taheran, M.; Naghdi, M.; Brar, S.K.; Knystautas, E.J.; Verma, M.; Surampalli, R.Y. Degradation of chlortetracycline using immobilized laccase on polyacrylonitrile-biochar composite nanofibrous membrane. Sci. Total Environ. 2017, 605, 315-321. [CrossRef]

67. Mansor, A.F.; Mohidem, N.A.; Zawawi, W.N.I.W.M.; Othman, N.S.; Endud, S.; Mat, H. The optimization of synthesis conditions for laccase entrapment in mesoporous silica microparticles by response surface methodology. Microporous Mesoporous Mater. 2016, 220, 308-314. [CrossRef]

68. Canbolat, M.F.; Basri, H.; Gultekin, F. Enzymatic behavior of laccase following interaction with $\gamma$-CD and immobilization into PCL nanofibers. Anal. Biochem. 2017, 528, 13-18. [CrossRef] 
69. Dai, Y.; Yao, J.; Song, Y.; Liu, X.; Wang, S.; Yuan, Y. Enhanced performance of immobilized laccase in electrospun fibrous membranes by carbon nanotubes modification and its application for bisphenol A removal from water. J. Hazard. Mater. 2016, 317, 485-493. [CrossRef]

70. Zhang, S.; Wu, Z.; Chen, G.; Wang, Z. An improved method to encapsulate laccase from Trametes vesrsicolor with enhanced stability and catalytic activity. Catalysts 2018, 286, 1-11.

71. Gill, J.; Orsat, V.; Kermasha, S. Optimization of encapsulation of a microbial laccase enzymatic extract using selected matrices. Process Biochem. 2018, 65, 55-61. [CrossRef]

72. Oliveira, S.F.; da Luz, J.M.R.; Kasuya, M.C.M.; Ladeira, L.O.; Junior, A.C. Enzymatic extract containing lignin peroxidase immobilized on carbon nanotubes: Potential biocatalyst in dye decolourization. Saudi J. Biol. Sci. 2018, 25, 651-659. [CrossRef] [PubMed]

73. Xu, R.; Tang, R.; Zhou, Q.; Li, F.; Zhang, B. Enhancement of catalytic activity of immobilized laccase for diclofenac biodegradation by carbon nanotubes. Chem. Eng. J. 2015, 262, 88-95. [CrossRef]

74. Ji, C.; Hou, J.; Chen, V. Cross-linked carbon nanotubes-based biocatalytic membranes for micro-pollutants degradation: Performance, stability, and regeneration. J. Membr. Sci. 2016, 520, 869-880. [CrossRef]

75. $\mathrm{Xu}, \mathrm{D}$;; Yang, Z. Cross-linked tyrosinase aggregates for elimination of phenolic compounds from wastewater. Chemosphere 2013, 92, 391-398. [CrossRef]

76. Xu, R.; Zhou, Q.; Li, F.; Zhang, B. Laccase immobilization on chitosan/poly(vinyl alcohol) composite nanofibrous membranes for 2,4-dichlorophenol removal. Chem. Eng. J. 2013, 222, 321-329. [CrossRef]

77. Palvannan, T.; Saravanakumar, T.; Unnithan, A.R.; Chung, N.; Kim, D.; Park, S. Efficient transformation of phenyl urea herbicide chloroxuron by laccase immobilized on zein polyurethane nanofiber. J. Mol. Catal. B Enzym. 2014, 99, 156-162. [CrossRef]

78. Xu, R.; Si, Y.; Wu, X.; Li, F.; Zhang, B. Triclosan removal by laccase immobilized on mesoporous nanofibers: Strong adsorption and efficient degradation. Chem. Eng. J. 2014, 255, 63-70. [CrossRef]

79. Jahangiri, E.; Thomas, I.; Schulze, A.; Seiwert, B.; Cabana, H.; Schlosser, D. Characterisation of electron beam irradiation-immobilised laccase for application in wastewater treatment. Sci. Total Environ. 2018, 624, 309-322. [CrossRef]

80. Ma, H.; Meng, G.; Cui, B.; Si, J.; Dai, Y. Chitosan crosslinked with genipin as supporting matrix for biodegradation of synthetic dyes: Laccase immobilization and characterization. Chem. Eng. Res. Des. 2018, 132, 664-676. [CrossRef]

81. Ba, S.; Haroune, L.; Cruz-Morato, C.; Jacquet, C.; Touahar, I.E.; Philippe-Bellenger, J.; Legault, C.Y.; Jones, J.P.; Cabana, H. Synthesis and characterization of combined cross-linked laccase and tyrosinase aggregates transforming acetaminophen as a model phenolic compound in wastewaters. Sci. Total Environ. 2014, 487, 748-755. [CrossRef] [PubMed]

82. Valerio, S.G.; Alves, J.S.; Klein, M.P.; Rodrigues, R.C.; Hertz, P.F. High operational stability of invertase from Saccharomyces cerevisiae immobilized on chitosan nanoparticles. Carbohydr. Polym. 2013, 92, 462-468. [CrossRef] [PubMed]

83. Shi, L.; Ma, F.; Han, Y.; Zhang, X.; Yu, H. Removal of sulfonamide antibiotics by oriented immobilized laccase on Fe3O4 nanoparticles with natural mediators. J. Hazard. Mater. 2014, 279, 203-211. [CrossRef] [PubMed]

84. Yaohua, G.; Ping, X.; Feng, J.; Keren, S. Co-immobilization of laccase and ABTS onto novel dual-functionalized cellulose beads for highly improved biodegradation of indole. J. Hazard. Mater. 2019, 365, 118-124. [CrossRef]

85. Fatarella, E.; Spinelli, D.; Ruzzante, M.; Pogni, R. Nylon 6 film and nanofiber carriers: Preparation and laccase immobilization performance. J. Mol. Catal. B Enzym. 2018, 351, 985-994. [CrossRef]

86. Lonappan, L.; Liu, Y.; Rouissi, T.; Pourcel, F.; Brar, S.K.; Verma, M.; Surampalli, R.Y. Covalent immobilization of laccase on citric acid functionalized micro-biochars derived from different feedstock and removal of diclofenac. Chem. Eng. J. 2018, 351, 985-994. [CrossRef]

87. Wan, D.; Tian, L.; Li, X.; Li, B.; Zhang, Q. A versatile strategy for enzyme immobilization: Fabricating lipase/inorganic hybrid nanostructures on macroporous resins with enhanced catalytic properties. Biochem. Eng. J. 2018, 139, 101-108. [CrossRef]

88. Shao, B.; Liu, Z.; Zheng, G.; Liu, Y.; Yang, X.; Zhou, C.; Chen, M.; Liu, Y.; Jiang, Y.; Yan, M. Immobilization of laccase on hollow mesoporous carbon nanospheres: Noteworthy immobilization, excellent stability and efficacious for antibiotic contaminants removal. J. Hazard. Mater. 2019, 362, 318-326. [CrossRef] 
89. Maryšková, M.; Ardao, I.; García-González, C.A.; Martinová, L.; Rotková, J.; Ševců, A. Polyamide 6/chitosan nanofibers as support for the immobilization of Trametes versicolor laccase for the elimination of endocrine disrupting chemicals. Enzym. Microb. Technol. 2016, 89, 31-38. [CrossRef]

90. Wang, Q.; Cui, J.; Li, G.; Zhang, J.; Li, D.; Huang, F.; Wei, Q. Laccase immobilized on a PAN/adsorbents composite nanofibrous membrane for catechol treatment by a biocatalysis/adsorption process. Molecules 2014, 19, 3376-3388. [CrossRef]

91. Misra, N.; Kumar, V.; Goel, N.K.; Varshney, L. Laccase immobilization on radiation synthesized epoxy functionalized polyethersulfone beads and their application for degradation of acid dye. Polymer 2014, 55, 6017-6024. [CrossRef]

92. Machado, A.; Tavares, A.P.M.; Rocha, C.M.R.; Cristóvão, R.O.; Teixeira, J.A.; Macedo, E.A. Immobilization of commercial laccase on spent grain. Process Biochem. 2012, 47, 1095-1101.

93. Taheran, M.; Naghdi, M.; Brar, S.K.; Knystautas, E.J.; Verma, M.; Surampalli, R.Y. Covalent immobilization of laccase onto nanofibrous membrane for degradation of pharmaceutical residues in water. ACS Sustain. Chem. Eng. 2017, 5, 10430-10438. [CrossRef]

94. Sathishkumar, P.; Kamala-Kannan, S.; Cho, M.; Kim, J.S.; Hadibarata, T.; Salim, M.R.; Oh, B.T. Laccase immobilization on cellulose nanofiber: The catalytic efficiency and recyclic application for simulated dye effluent treatment. J. Mol. Catal. B Enzym. 2014, 100, 111-120. [CrossRef]

95. El Aty, A.A.A.; Mostafa, F.A.; Hassan, M.E.; Hamed, E.R.; Esawy, M.A. Covalent immobilization of Alternariatenuissima KM651985 laccase and some applied aspects. Biocatal. Agric. Biotechnol. 2017, 9, 74-81. [CrossRef]

96. Li, G.; Nandgaonkar, A.G.; Lu, K.; Krause, W.E.; Lucia, L.A.; Wei, Q. Laccase immobilized on PAN/O-MMT composite a de novo adsorption and biocatalytic synergy. RSC Adv. 2016, 6, 41420-41427. [CrossRef]

97. Olajuyigbe, F.M.; Adetuyi, Y.; Fatokun, C.O. Characterization of free and immobilized laccase from Cyberlindnerafabianii and application in degradation of bisphenol A. Int. J. Biol. Macromol. 2019, 125, 856-864. [CrossRef]

98. Jaiswal, N.; Pandey, V.P.; Dwivedi, U.N. Purification of a thermostable laccase from Leucaenaleucocephala using a copper alginate entrapment approach and the application of the laccase in dye decolorization. Process Biochem. 2014, 49, 1196-1204. [CrossRef]

99. Jiang, X.; Yu, Y.; Li, X.; Kong, X.Z. High yield preparation of uniform polyurea microspheres through precipitation polymerization and their application as laccase immobilization support. Chem. Eng. J. 2017, 328, 1043-1050. [CrossRef]

100. Wen, X.; Du, C.; Wan, J.; Zheng, G.; Huang, D.; Yin, L.; Deng, R.; Tan, S.; Zhang, J. Immobilizing laccase on kaolinite and its application in treatment of malachite green effluent with the coexistence of $\mathrm{Cd}(\Pi)$. Chemosphere 2019, 217, 843-850. [CrossRef]

101. Yuan, H.; Chen, L.; Hong, F.F.; Zhu, M. Evaluation of nanocellulose carriers produced by four different bacterial strains for laccase immobilization. Carbohydr. Polym. 2018, 196, 457-464. [CrossRef] [PubMed]

102. Samak, N.A.; Tan, Y.; Sui, K.; Xia, T.; Wang, K.; Guo, C.; Liu, C. CotA laccase immobilized on functionalized magnetic graphene oxide nano-sheets for efficient biocatalysis. Mol. Catal. 2018, 445, 269-278. [CrossRef]

103. Saoudi, O.; Ghaouar, N. Biocatalytic characterization of free and immobilized laccase from Trametes versicolor in its activation zone. Int. J. Biol. Macromol. 2019, 128, 681-691. [CrossRef] [PubMed]

104. Chen, C.; Lu, Y.; Lin, J.; Hu, C.; Tsai, H. Quick screening of true tyrosinase inhibitors from natural products using tyrosinase-immobilized magnetic nanoparticles and a magnetic microplate. J. Chin. Chem. Soc. 2018, 65, 1075-1081. [CrossRef]

105. Stapelberg, J.; Nqephe, M.; Lambrechts, I.; Crampton, B.; Lall, N. Selected South African plants with tyrosinase enzyme inhibition and their effect on gene expression. S. Afr. J. Bot. 2018, 10, 6-11. [CrossRef]

106. Jaiswal, N.; Pandey, V.P.; Dwivedi, U.N. Immobilization of papaya laccase in chitosan led to improved multipronged stability and dye discoloration. Int. J. Biol. Macromol. 2016, 86, 288-295. [CrossRef] [PubMed]

107. Drozd, R.; Rakoczy, R.; Wasak, A.; Junka, A.; Fijałkowski, K. The application of magnetically modified bacterial cellulose for immobilization of laccase. Int. J. Biol. Macromol. 2018, 108, 462-470. [CrossRef]

108. Liu, C.; Saeki, D.; Cheng, L.; Luo, J.; Matsuyama, H. Polyketone-based membrane support improves the organic solvent resistance of laccase catalysis. J. Colloid Interface Sci. 2019, 544, 230-240. [CrossRef] 
109. Touahar, I.E.; Haroune, L.; Ba, S.; Bellenger, J.; Cabana, H. Characterization of combined cross-linked enzyme aggregates from laccase, versatile peroxidase and glucose oxidase, and their utilization for the elimination of pharmaceuticals. Sci. Total Environ. 2014, 481, 90-99. [CrossRef]

110. Hassani, T.; Ba, S.; Cabana, H. Formation of enzyme polymer engineered structure for laccase and cross-linked laccase aggregates stabilization. Bioresour. Technol. 2013, 128, 640-645. [CrossRef]

111. Yildiz, H.B.; Caliskan, S.; Kamaci, M.; Caliskan, A.; Yilmaz, H. L-Dopa synthesis catalyzed by tyrosinase immobilized in poly(ethyleneoxide) conducting polymers. Int. J. Biol. Macromol. 2013, 56, 34-40. [CrossRef] [PubMed]

112. Kashefi, S.; Borghei, S.M.; Mahmoodi, N.M. Covalently immobilized laccase onto graphene oxide nanosheets: Preparation, characterization, and biodegradation of azo dyes in colored wastewater. J. Mol. Liq. 2019, 276, 153-162. [CrossRef]

(C) 2020 by the authors. Licensee MDPI, Basel, Switzerland. This article is an open access article distributed under the terms and conditions of the Creative Commons Attribution (CC BY) license (http://creativecommons.org/licenses/by/4.0/). 